\title{
Evolução crustal do setor ocidental do Bloco Arqueano Gavião, Cráton do São Francisco, com base em evidências $\mathrm{U}-\mathrm{Pb}, \mathrm{Sm}-\mathrm{Nd}$ e Rb-Sr

\author{
Crustal evolution of the western part of the Archean Gavião Block, \\ São Francisco Craton, based on U-Pb, Sm-Nd and Rb-Sr evidence
}

\author{
Natali da Silva Barbosa1, Wilson Teixeira², Luiz Rogério Bastos Leal ${ }^{3}$, Angela Beatriz de Menezes Leal ${ }^{3}$ \\ ${ }^{1}$ Programa de Pós-graduação em Geoquímica e Geotectônica, Instituto de Geociências, \\ Universidade de São Paulo - USP, Rua do Lago 562, CEP 05508-080, São Paulo, SP, BR (natali@usp.br) \\ ${ }^{2}$ Centro de Pesquisas Geocronológicas, Instituto de Geociências, Universidade de São Paulo - USP, \\ São Paulo, SP, BR (wteixeir@usp.br) \\ ${ }^{3}$ Programa de Pós-graduação em Geologia, Departamento de Geologia e Geofísica, Instituto de Geociências, \\ Universidade Federal da Bahia - UFBA, Salvador, BA, BR (Irogerio@ufba.br; angelab@ufba.br)
}

Recebido em 11 de abril de 2013; aceito em 03 de setembro de 2013

\begin{abstract}
Resumo
O Bloco Gavião Oeste, Cráton do São Francisco, um dos segmentos mais primitivos da Plataforma Sul-Americana, é constituído pelos complexos Gnáissico Migmatítico Riacho de Santana e Santa Isabel, além do greenstone belt Riacho de Santana. As idades $\mathrm{T}_{\mathrm{DM}}$ em rochas dessas unidades revelam que as épocas acrescionárias principais nesse setor do Bloco Gavião foram: 3,9 Ga; 3,2 - 3,0 Ga e 2,6 Ga. O Complexo Gnáissico Migmatítico apresenta idade U-Pb mais antiga para o embasamento (3648 $\pm 69 \mathrm{Ma}$ ), enquanto que o valor negativo de $\varepsilon_{\mathrm{Ndt}}$ é compatível com retrabalhamento crustal. Em adição, uma isócrona de referência $\mathrm{Rb}$-Sr forneceu idade de $3247 \pm 120 \mathrm{Ma}$, tentativamente interpretada como evento de migmatização. A idade U-Pb de cristalização de uma rocha do Complexo Santa Isabel é $2954 \pm 100$ Ma, havendo migmatização há $2748 \pm 100 \mathrm{Ma}$, conforme isócrona de referência Rb-Sr. Os respectivos valores de $\varepsilon_{\mathrm{Ndt}}$ variam entre $-4,7$ e $+0,3$ que, somados às idades $\mathrm{T}_{\mathrm{DM}}(3,3-3,1 \mathrm{Ga})$, sugerem a derivação dessas rochas a partir de protólitos mesoarqueanos com curta residência crustal. O greenstone belt Riacho de Santana formou-se há $2218 \pm 18 \mathrm{Ma}$, com base em idade U-Pb em zircão em metabasaltos (toleítos) da unidade intermediária. Pelo menos para uma das amostras, os dados Sm-Nd indicaram fracionamento anômalo, enquanto outra tem idade $\mathrm{T}_{\mathrm{DM}}$ de $2,6 \mathrm{Ga}$, indicando significativa contribuição crustal na gênese desse magmatismo. O Bloco Gavião Ocidental foi intrudido pelo batólito Guanambi (U/Pb $=2054 \pm 8 \mathrm{Ma})$ com gênese associada a protólitos arqueanos $\left(\mathrm{T}_{\mathrm{DM}}=2,8-2,7 \mathrm{Ga}\right)$. Eventos superpostos ocorreram durante o Meso e o Neoproterozoico, conforme idades K-Ar e U-Pb (intercepto inferior de discórdia) em rochas do Complexo Gnáissico Migmatítico Riacho de Santana. Esse fato é interpretado como reflexo da evolução do sistema intracratônico Espinhaço setentrional e da influência tectonotermal do ciclo Brasiliano no Corredor do Paramirim.
\end{abstract}

Palavras-chave: Cráton do São Francisco; Bloco Gavião; Greenstone belt Riacho de Santana; Geoquímica isotópica; Geocronologia U-Pb.

\begin{abstract}
The western part of the Gavião Block (São Francisco Craton) is one of the oldest fragments of the South American Platform. It comprises the Riacho de Santana Gneissic Migmatitic complex, the Santa Isabel complex and the Riacho de Santana greenstone belt. $\mathrm{T}_{\mathrm{DM}}$ ages of country rocks of these units reveal that the main accretion periods were: $3.9 \mathrm{Ga}, 3.2-3.0 \mathrm{Ga}$ and $2.6 \mathrm{Ga}$. The Gneissic Migmatitic complex yields $\mathrm{U}-\mathrm{Pb}$ age of $3648 \pm 69 \mathrm{Ma}$, while the negative $\varepsilon_{\mathrm{Ndt}}$ value is compatible with crustal reworking. The $\mathrm{Rb}-\mathrm{Sr}$ isochron provided age of $3247 \pm 120 \mathrm{Ma}$, tentatively interpreted as migmatization event. U-Pb data indicate that crystallization of a rock from the Santa Isabel Complex occurred at $2954 \pm 100 \mathrm{Ma}$ ago, with migmatization at $2748 \pm 100 \mathrm{Ma}$ ago ( $\mathrm{Rb}-\mathrm{Sr}$ isochron). This complex displays $\mathrm{T}_{\mathrm{DM}}$ ages of $3.3-3.1 \mathrm{Ga}$ and variable $\varepsilon_{\mathrm{Ndt}}$ parameters $(-4.7$ to +0.3$)$, which suggest juvenile and reworking processes from Mesoarchean protholiths with short crustal residence time. Relative the metamafic (tholeiitic) rock from the Riacho de Santana greenstone belt, at least one of
\end{abstract}


the samples indicates anomalous fractionation, yields a $2.6 \mathrm{Ga} \mathrm{T}_{\mathrm{DM}}$ age whereas the U-Pb crystallization age is $2218 \pm 18 \mathrm{Ma}$. This suggests crustal contamination of the particular mantle source. Shortly after, the country rocks were intruded by the $(\mathrm{U} / \mathrm{Pb}=2054 \pm 8 \mathrm{Ma})$ Guanambi batholith which was mainly derived from Archean protholiths ( $\mathrm{T}_{\mathrm{DM}}$ ages of $\left.2.8-2.7 \mathrm{Ga}\right)$. Eventually, tectonic and thermal overprints took place in the study area during Meso- and Neoproterozoic periods, as indicated by K-Ar apparent ages and lower intercept age of a U-Pb discordia line from rocks of the Riacho de Santana Gneissic Migmatitic Complex. We believe that these younger episodes reflect the onset of the Northern Espinhaço intracratonic system and the Neoproterozoic dynamics, respectively, as similar as recorded over the Paramirim Corridor.

Keywords: São Francisco Craton; Gavião Block; Riacho de Santana greenstone belt; Isotopic geochemistry; U-Pb geochronology.

\section{INTRODUÇÃO E ARCABOUÇO TECTÔNICO}

O Cráton do São Francisco (CSF; Almeida, 1977), localizado na porção centro-leste da Plataforma Sul-Americana (Figura 1A), compreende segmentos crustais arqueanos e paleoproterozoicos (Cordani et al., 1992; Alkmim et al., 1993; Teixeira et al., 1996; Oliveira et al., 2010). No Estado da Bahia, a crosta primitiva foi edificada por meio de vários processos orogenéticos, com destaque para a geração de associações granito-greenstone e terrenos metamórficos de médio a alto grau (Barbosa e Sabaté, 2004; Barbosa et al., 2012). De acordo com o acervo de dados $\mathrm{U}-\mathrm{Pb}$, Sm-Nd e Rb-Sr, os eventos orogenéticos mais primitivos identificados regionalmente podem ser sumarizados como segue: domínios crustais distintos com idades do Paleoarqueano (3,6-3,2 Ga), com greenstone belts $(3,3-3,0 \mathrm{Ga})$ e rochas granitoides de composição TTG (tonalito-trondjemito-granodiorito) com idades entre 3,2 e 2,9 Ga (Martin et al., 1997; Rios et al., 2008, 2009; Dantas et al., 2010; Oliveira et al., 2010; Teixeira et al., 2010).

Durante o Paleoproterozoico, os processos acrescionários e colisionais edificaram a crosta continental do paleocontinente São Francisco. Esses processos foram marcados pelo desenvolvimento de arcos magmáticos, cujos produtos vulcano-plutônicos mostram idades entre 2,2 e 1,9 Ga e geração de greenstone belts, a exemplo do Itapicuru (Silva, 1996; Conceição et al., 2002; Rios, 2002; Barbosa et al., 2008; Oliveira et al., 2010). Em consequência, estabeleceu-se uma arquitetura de blocos arqueanos (Gavião, Jequié, Serrinha e Uauá) circundados por cinturões móveis paleoproterozoicos (Cordani, 1973; Marinho, 1991; Barbosa e Dominguez, 1996; Barbosa e Sabaté, 2004; Rios et al., 2009; Oliveira et al., 2010, 2011; Barbosa et al., 2012). Em função do exposto, pode-se afirmar que os eventos que construíram a crosta continental na porção setentrional do CSF foram de natureza policíclica e abrangeram o Arqueano e o Paleoproterozoico.

O setor ocidental do Bloco Gavião (Figura 1B), anteriormente denominado Bloco Guanambi Correntina (e.g., Brito Neves et al., 1980; Barbosa e Dominguez, 1996), tem sido nomeado por muitos geólogos de forma diversa. Atribui-se tal falta de consenso ao conhecimento geológico incipiente na área de estudo, o que não favoreceu uma classificação tectônica mais apropriada. Segundo a síntese de Barbosa et al. (2012), a região passa a ser incorporada no recém-denominado Bloco Gavião Oeste (BGO), nomenclatura a ser adotada neste estudo.

A área-foco deste trabalho, a porção BGO (Figura 2) expõe relíquias dos terrenos granito-greenstone arqueanos e exposições de rochas de médio a alto grau metamórfico, representando o substrato primitivo. Ela situa-se a oeste do Bloco Gavião Sul (Figura 1B), a leste da área afetada pelo sistema Espinhaço Setentrional (1,7 - 0,8 Ga) e magmatismo coevo (e.g., complexo Lagoa Real; Cordani et al., 1992) e o Corredor do Paramirim (650 - $500 \mathrm{Ma}$ ) (e.g., Teixeira et al., 2000; Alkmim, 2004; Danderfer et al., 2009).

O propósito deste trabalho é ampliar a compreensão da evolução crustal do BGO, com base especialmente na compilação, reavaliação e recálculo de idades radiométricas publicadas, aliada à interpretação de dados inéditos (U-Pb zircão/LA-ICPMS, $\mathrm{Pb}-\mathrm{Pb}$ por evaporação de zircão) e isotópicos ( $\mathrm{Sm}-\mathrm{Nd})$ em rochas do substrato e do greenstone belt Riacho de Santana. Para esse fim, foram selecionadas no BGO rochas do embasamento (Complexo Gnáissico Migmatítico Riacho de Santana e Complexo Santa Isabel Companhia de Pesquisa de Recursos Minerais [CPRM], 2004; Mascarenhas, 1979), da sequência greenstone belt Riacho de Santana (Silveira, 1994) e rochas plutônicas e vulcânicas do batólito Guanambi, este último definido por Rosa (1999). O resultado deste trabalho também ilustra o potencial interpretativo de dados isotópicos em uma abordagem integrada, para investigar o contexto evolutivo de diferentes tipos de rochas em um dado ambiente tectônico. Não obstante reconhecermos que os métodos geocronológicos tradicionais (e.g., isócronas de referência $\mathrm{Rb}-\mathrm{Sr}$ ) têm potencial interpretativo limitado, comparativamente aos métodos U-Pb e Sm-Nd, consideramos que a interpretação dos diagramas isocrônicos de referência, aqui realizada, é útil para delinear eventos superpostos de re-homogeneização isotópica regional.

\section{CONTEXTO GEOLÓGICO REGIONAL - BLOCO GAVIÃO OESTE}

O Bloco Gavião expõe as rochas mais antigas do CSF, especialmente no Estado da Bahia. As rochas possuem uma diversificada cronologia, a qual experimentou diferentes 

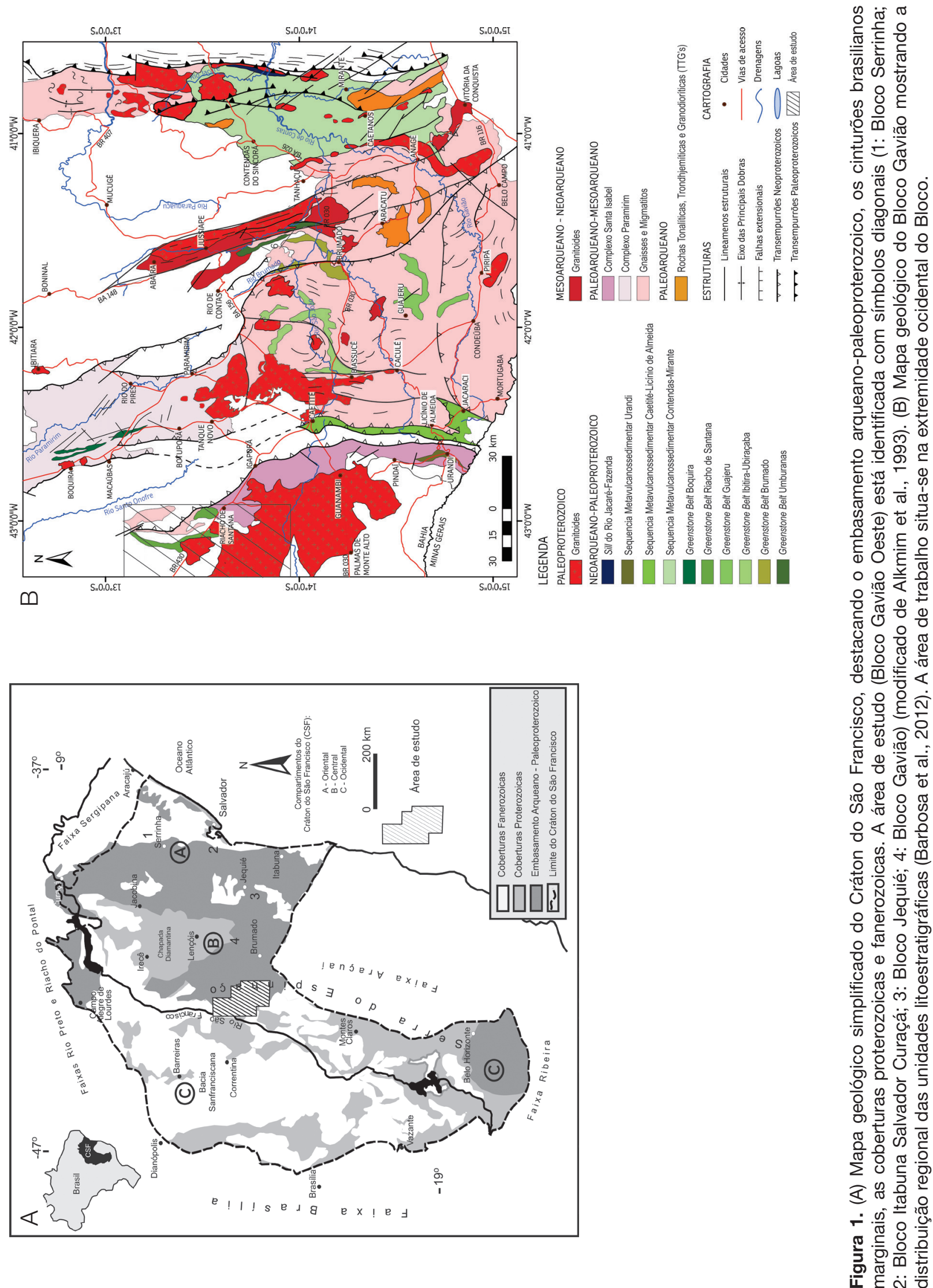
ambientes de geração e deformação. Esse segmento crustal é composto por rochas de afinidade TTG metamorfisadas em diferentes graus, com idades de até 3,4 Ga em seu setor sul (Marinho, 1991; Martin et al., 1991). O embasamento arqueano encontra-se migmatizado e gnaissificado com relíquias de granulitos, enquanto os granitos paleoproterozoicos são de caráter sin- e pós-tectônicos. Por outro lado, os greenstone belts (e.g., Brumado, Umburanas, Guajeru - Figura 1B) e as sequências vulcanossedimentares apresentam idades arqueanas, com fácies metamórfica predominantemente xisto verde (Barbosa et al., 2012).

A porção oeste do Bloco Gavião é composta de terrenos granito-gnáissicos migmatizados e relíquias de sequências greenstone belts, um deles (Riacho de Santana) tratado no presente trabalho. Essas unidades litoestratigráficas são cortadas por rochas granitoides (e.g., Barbosa e Dominguez, 1996; Rosa et al., 2000; Silveira e Garrido, 2000 - Figura 2). Assim como em outros segmentos crustais arqueanos da porção setentrional do CSF (e.g., Bloco Gavião sul e central, Bloco Jequié, Bloco Serrinha, ver Figura 1A), no BGO são também reconhecidos eventos tectono-metamórficos e de retrabalhamento crustal durante o Paleoproterozoico em que o metamorfismo granulítico tem sido considerado com idade entre 2,2 e 2,0 Ga (Barbosa e Dominguez, 1996; Barbosa e Sabaté, 2004; Oliveira et al., 2010).

A porção leste do BGO é, por sua vez, recoberta por escamas tectônicas com rochas do Grupo Santo Onofre. Trata-se de rochas metassedimentares de natureza detrítica e química, associadas à evolução do rifte Espinhaço, desenvolvido em 3 estágios temporais: 1,73, 1,57 e 0,85 Ga (Danderfer et al., 2009; Alkmim e Martins-Neto, 2012). Esse rifte possui uma evolução intracratônica com magmatismo precoce, como vulcanismo extensional associado com plutonismo anorogênico (complexo Lagoa Real, $1725 \mathrm{Ma}$ - Turpin et al., 1988), ciclos deposicionais e colocação de enxames de diques máficos $(0,85 \mathrm{Ga})$. Especificamente as rochas do Grupo Santo Onofre, que preenchem um dos ramos do rifte, registram o último estágio de deposição sedimentar do Espinhaço setentrional $(0,90-0,85 \mathrm{Ga})$ e suas características são compatíveis com o desenvolvimento de uma bacia transtensional (Danderfer et al., 2009). A evolução do Espinhaço deixou seu registro tectono-termal nas diversas litologias do BGO. Registre-se ainda que as rochas do batólito Guanambi aparentemente foram rejuvenescidas no Cambriano, conforme registro $\mathrm{K} / \mathrm{Ar}$ de $527 \mathrm{Ma}$ (Távora et al., 1967). Essa idade possivelmente reflete a deformação intracratônica e eventos tectonotermais que afetaram o Corredor do Paramirim (e.g., Alkmim, 2004) e rochas basais adjacentes, ou seja, o Bloco Gavião oeste e central. Conforme sintetizado por Alkmim e Martins Neto (2012), o Corredor do Paramirim corresponde a um rifte formado no Mesoproterozoico e, posteriormente, durante o Neoproterozoico foi afetado por deformação regional e reativação tectônica em decorrência do desenvolvimento dos cinturões marginais Riacho do Pontal e Araçuaí (Cruz, 2004; Cruz e Alkmim, 2007; Schobbenhaus, 1996; Alkmim e Martins Neto, 2012).

Finalmente, as coberturas do Neoproterozoico correlacionadas ao Supergrupo São Francisco recobrem a extensão ocidental do BGO, sendo constituídas por uma sequência terrígena basal e uma fácies carbonática no topo do Grupo Bambuí. Sedimentos de idade terciária e quaternária recobrem a porção norte do embasamento (Silveira e Garrido, 2000 - Figura 2).

Estudos geocronológicos pioneiros realizados no BGO foram baseados essencialmente em datações K-Ar e Rb-Sr (e.g., Távora et al., 1967; Jardim de Sá et al., 1976; Brito Neves et al., 1980; Fernandes et al., 1982; Cordani et al., 1985; Mascarenhas e Garcia, 1989). Posteriormente, esse segmento cratônico foi alvo de investigações geocronológicas por vários métodos combinados (e.g., Rb-Sr, $\mathrm{Pb}-\mathrm{Pb}, \mathrm{Sm}-\mathrm{Nd}$ e U-Pb - Rosa, 1999). Mais recentemente, Barbosa (2010) reavaliou o contexto geocronológico do $\mathrm{BGO}$, com a adição de novos dados U-Pb, $\mathrm{Pb}-\mathrm{Pb}$ e $\mathrm{Sm}-\mathrm{Nd}$, conforme será destacado adiante. As principais características das unidades litoestratigráficas regionais que constituem o substrato metamórfico (complexos Santa Isabel e Gnáissico Migmatítico), o greenstone belt Riacho de Santana e as rochas granitoides intrusivas, estão sintetizadas a seguir.

\section{Complexo Gnáissico Migmatítico Riacho de Santana}

As rochas dessa unidade expõem-se na porção nordeste da área estudada (Figura 2), sendo principalmente ortognaisses, migmatitos e granulitos de composição TTG. Desse conjunto, predomina um gnaisse de granulação fina a média, localmente porfirítico. Enclaves de rochas máficas são comuns. Eles são cataclásticos, miloníticos, lineados e, algumas vezes, são homogêneos, dobrados e/ou boudinados concordantemente com as rochas encaixantes. O Complexo Gnáissico Migmatítico Riacho de Santana encontra-se variavelmente afetado por migmatização e por K-feldspatização, interpretados como associados a processos ocorridos durante o Paleoproterozoico (Moutinho da Costa e Silva, 1980). Os contatos desse complexo com outras unidades, embora geralmente cobertos por sedimentos, são tectônicos. Por exemplo, o contato com o greenstone belt Riacho de Santana é uma zona de cisalhamento sinistral, enquanto que o contato com o grupo Serra Geral (Sistema Espinhaço) é por falha inferida em escala de foto aérea (Silveira e Garrido, 2000).

Para as rochas do Complexo Gnáissico Migmatítico Riacho de Santana, foi reportada uma idade $\mathrm{Rb} / \mathrm{Sr}$ 


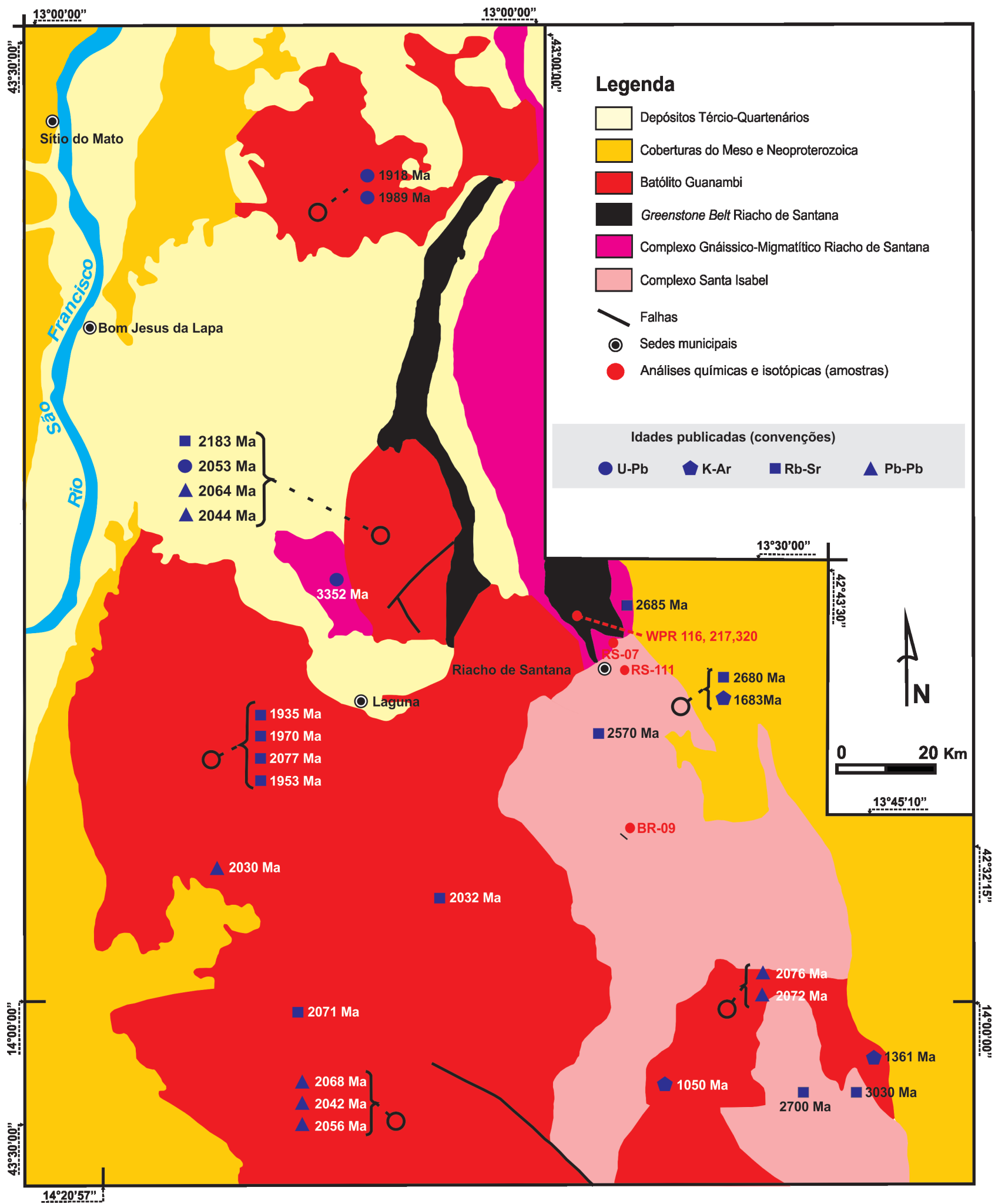

Fonte: modificado de Rosa (1999).

Figura 2. Mapa geológico da porção Bloco Gavião Oeste mostrando a distribuição regional das unidades litoestratigráficas e idades da literatura. 
isocrônica de referência com $2685 \pm 97$ Ma e razão inicial (R.I.) de ${ }^{87} \mathrm{Sr}^{186} \mathrm{Sr}_{\mathrm{i}(\mathrm{t}=2,7 \mathrm{Ga})}=0,705$ (Anexo 1; Mascarenhas e Garcia, 1989), a qual foi então interpretada como de um evento de migmatização regional. Contudo, parte das amostras dessa isócrona, considerando-se a cartografia de Silveira e Garrido (2000), representaria o Complexo Santa Isabel. Uma idade $\mathrm{K} / \mathrm{Ar}$ (em biotita) em migmatito desse complexo indicou valor aparente de $1050 \pm 30$ Ma (Távora et al., 1967).

\section{Complexo Santa Isabel}

Silveira e Garrido (2000) consideram que as rochas do Complexo Santa Isabel foram formadas através de vários pulsos plutônicos de composição TTG, seguidos de eventos tectono-metamórficos e de retrabalhamento crustal. Esse conjunto, por sua vez, é cortado por diques máficos, cuja idade ainda não é conhecida. O Complexo Santa Isabel é constituído predominantemente por suítes charnockíticas (enderbitos, noritos, charnockitos, opdalitos e jotunitos), granulitos, gnaisses, tonalitos e migmatitos. Algumas dessas rochas possuem xenólitos de rochas básico-ultrabásicas. O metamorfismo varia da fácies granulito de alta a média pressão (Portela et al., 1976) a fácies anfibolito (Rosa et al., 1996). Cabe destacar que o Complexo Santa Isabel, à semelhança do complexo Riacho de Santana, foi submetido à migmatização e também afetado por K-feldspatização durante o Paleoproterozoico (Barbosa et al., 2003).

Os primeiros estudos geocronológicos no Complexo Santa Isabel foram realizados pelos métodos $\mathrm{K}-\mathrm{Ar}$ e $\mathrm{Rb}$ $\mathrm{Sr}$. As idades isocrônicas $\mathrm{Rb} / \mathrm{Sr}$ em rocha total possuem grande variação temporal de $3030 \pm 107 \mathrm{Ma}$ (Mascarenhas et al., 1985), $2700 \mathrm{Ma}, 2680 \pm 83 \mathrm{Ma}$ (Fernandes et al., 1982; Brito Neves et al., 1980), $2570 \pm 220$ Ma (Jardim de Sá et al., 1976), sugerindo o caráter policíclico da evolução crustal. Segundo Mascarenhas et al. (1985), a idade $\mathrm{Rb} / \mathrm{Sr}$ de 3,03 Ga obtida em granulitos, migmatitos e gnaisses definiria a época do metamorfismo de alto grau nesse complexo. Em relação às isócronas de idade em torno de 2,6 e $2,7 \mathrm{Ga}$, os diagramas isocrônicos incorporaram amostras não pertencentes ao Complexo Santa Isabel; assim, neste trabalho será apresentado um diagrama integrando apenas amostras consideradas desse complexo.

Os dados K-Ar em biotita para granitos e um gnaisse do Complexo Santa Isabel sugerem a presença de pelo menos um evento tectônico-metamórfico no intervalo 1750 - $1680 \mathrm{Ma}$ (Brito Neves et al., 1980; Mascarenhas et al., 1985). Essas idades aparentes podem ser tentativamente interpretadas como reflexo da evolução do sistema Espinhaço no Corredor Paramirim (e.g., Alkmim e Martins-Neto, 2012), que está situado em região adjacente ao BGO. Por outro lado, outra idade em biotita de cerca 1360 Ma (Mascarenhas et al., 1985) é aqui considerada como de significado dúbio, uma vez que o teor de $\mathrm{K}$ $(3,6 \%)$ é muito baixo para aquele mineral.

\section{Greenstone belt Riacho de Santana}

O greenstone belt Riacho de Santana aflora descontinuamente ao longo de uma faixa norte-sul, com aproximadamente $1.000 \mathrm{~km}^{2}$. Essa unidade vulcanossedimentar localiza-se entre o batólito Guanambi e o Complexo Gnáissico Migmatítico Riacho de Santana. É compartimentada em três unidades litoestratigráficas (Fróes e Silveira, 1996; Silveira e Garrido, 2000): (i) Unidade Inferior: compreende rochas metaultramáficas komatíticas com finas intercalações de metabasaltos e metagabros, associados a formações ferríferas bandadas (BIFs), quartzitos, metacherts, rochas cálcio-silicáticas, xistos aluminosos, metacarbonatos e metagrauvacas; (ii) Unidade Intermediária: constituída de metabasaltos e metagabros, metatufos de composição intermediária a ácida, xistos aluminosos, xistos grafitosos, actinolita xistos e metacherts; e (iii) Unidade Superior: constituída de uma sequência de quartzitos e metacarbonatos com manifestações discretas de metabasaltos e metatufos associados, além de sericita e clorita xistos.

A Figura 3 ilustra a estratigrafia do greenstone belt Riacho de Santana (adaptado de Silveira e Garrido, 2000), enquanto a Figura 4 apresenta a geologia local e a amostragem para o presente estudo. As rochas metavulcânicas máficas da Unidade Intermediária do greenstone belt Riacho

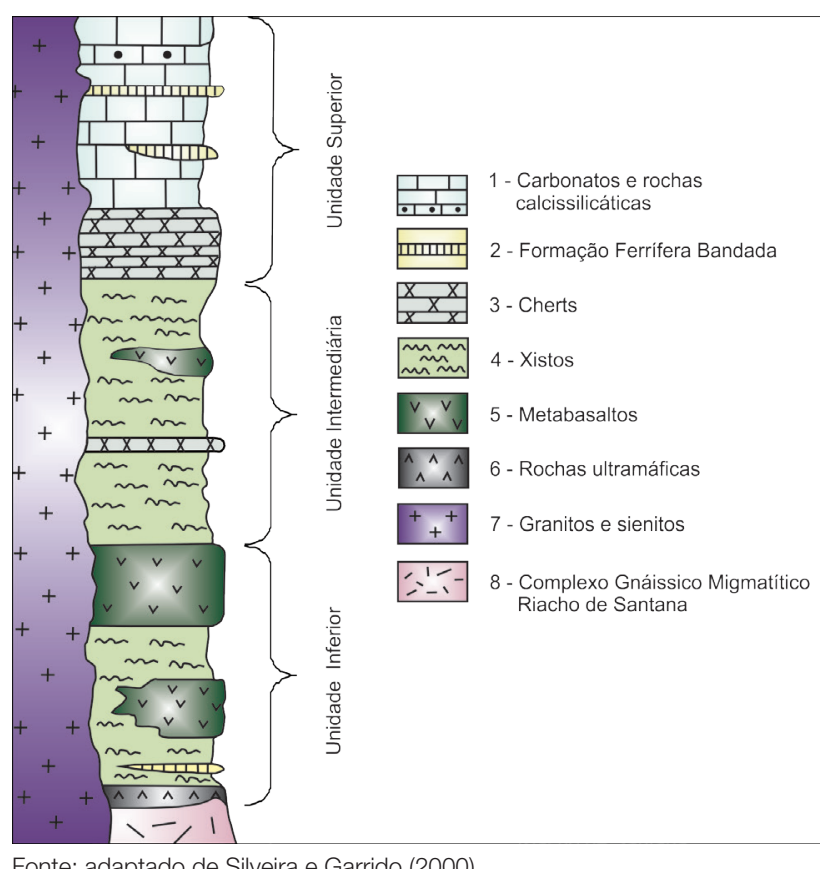

Figura 3. Coluna estratigráfica do greenstone belt Riacho de Santana. 


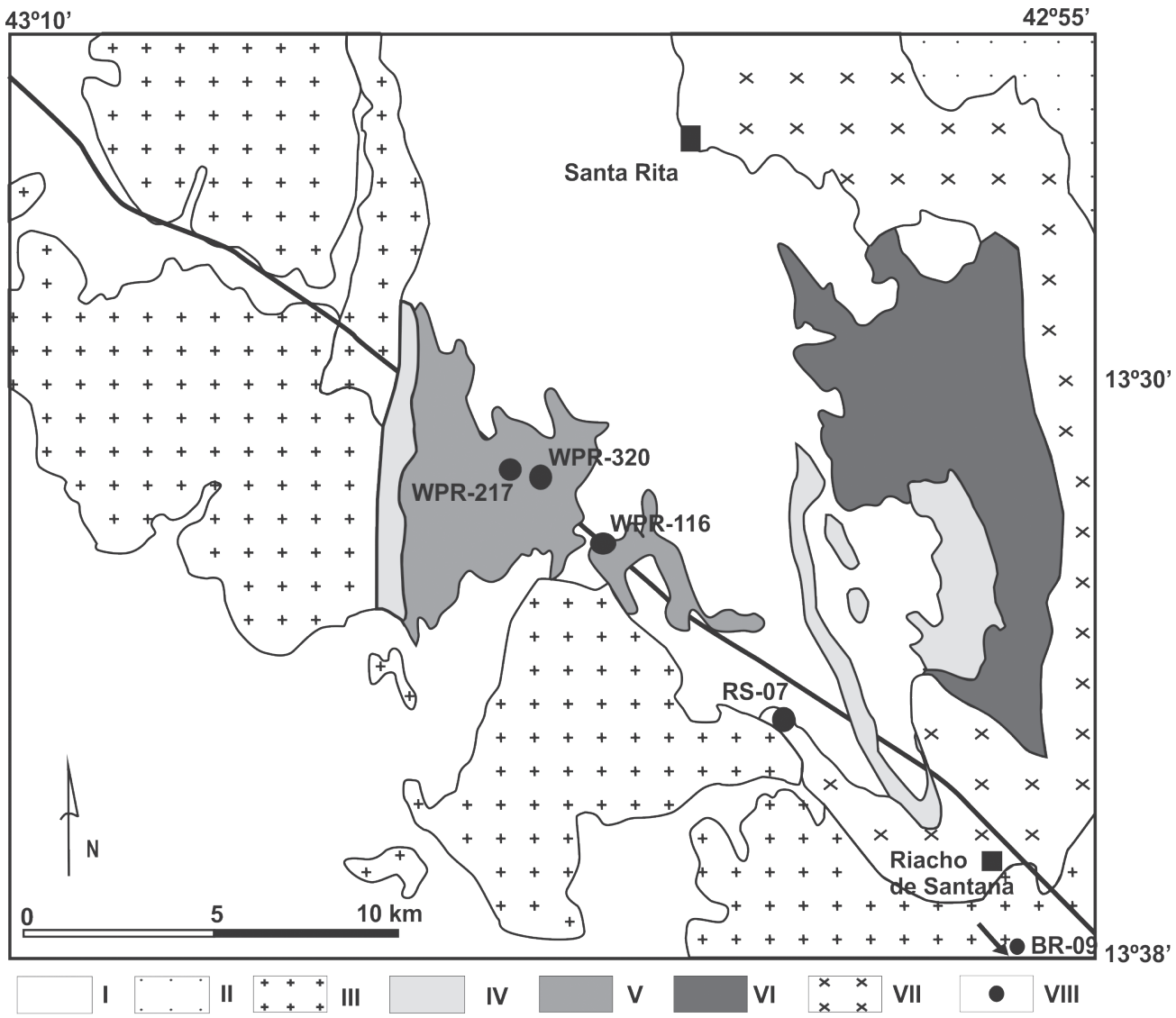

Principais unidades - Cenozoico: I: Aluvião e coberturas sedimentares detríticas; Mesoproterozoico (Grupo Serra Geral, Formações: Santo Onofre, Sítio Novo, Salto): II: Quartzitos, filitos, xistos e conglomerados; Paleoproterozoico: III: Álcali-sienitos e rochas granitoides (batólito Guanambi); Paleoproterozoico: greenstone belt Riacho de Santana; Unidade Superior: IV: Rochas carbonáticas e cálcio-silicáticas com metacherts e formações ferríferas bandadas; Unidade Intermediária: V: Metabasaltos e metagabros, metacherts, metatufos e xistos em geral; Unidade Inferior: VI: Rochas metaultramáficas komatíticas com intercalações de metabasaltos, metacherts, formações ferríferas bandadas e xistos em geral; Rochas do Embasamento: VII: Ortognaisses, migmatitos e ortognaisses granulitizados (complexo Gnáissico Migmatítico Riacho de Santana); VIII: Afloramento com análise química e/ou isotópica (amostras WPR217, WPR-320, WPR-116 e RS-07).

Figura 4. Mapa geológico do greenstone belt Riacho de Santana (modificado de Silveira e Garrido, 2000 apud Menezes Leal et al., 2008).

de Santana têm paragênese metamórfica característica da fácies xisto verde (Silveira e Garrido, 2000; Prazeres Santos, 2010).

As rochas metamáficas da unidade intermediária do greenstone belt Riacho de Santana são classificadas como toleítos ricos em ferro, com baixo conteúdo álcalis/sílica (Menezes Leal et al., 2008). Na evolução magmática dessas rochas, observa-se empobrecimento de $\mathrm{Cr}, \mathrm{Ni}, \mathrm{CaO}$ e $\mathrm{Al}_{2} \mathrm{O}_{3} \mathrm{e}$ enriquecimento de $\mathrm{SiO}_{2}, \mathrm{TiO}_{2}, \mathrm{FeO}_{\mathrm{t}}, \mathrm{K}_{2} \mathrm{O}, \mathrm{Na}_{2} \mathrm{O}$ e elementos incompatíveis. O comportamento geoquímico dos elementos maiores sugere forte controle do plagioclásio e clinopiroxênio no fracionamento magmático (Menezes Leal et al., 2008; Prazeres Santos, 2010). Por outro lado, o conteúdo de $\mathrm{MgO}$ diminui com o decréscimo de $\mathrm{Ni}$ e Sc, sugerindo que a cristalização de olivina e clinopiroxênio foram também importantes no fracionamento magmático. Em adição, padrões planos de Elementos Terra Rara (ETR) pesados e baixas razões entre ETR leves/ETR pesados indicam processos de fusão relativamente rasos com ausência de granada na fonte magmática. De outra parte, os padrões de ETR normalizados para o manto primitivo e razões $(\mathrm{Ba} / \mathrm{Zr}, \mathrm{Ba} / \mathrm{Nb}$, $\mathrm{Ti} / \mathrm{Y}, \mathrm{Nb} / \mathrm{Y}, \mathrm{Nb} / \mathrm{Th}$ e $\mathrm{Zr} / \mathrm{Y}$ ) para as rochas metamáficas da sequência greenstone plotaram entre os campos N-MORB e OIB. Isso demonstra que o magma progenitor foi derivado de fontes enriquecidas ou por mistura entre componentes enriquecidos e empobrecidos, contudo sem descartar a possibilidade de haver contaminação crustal. De fato, as razões entre elementos HFS apontam a presença de componentes do tipo OIB, ao passo que as anomalias negativas de Sr sugerem assimilação de material crustal pelo magma (Menezes Leal et al., 2008).

Uma amostra de metabasalto da unidade intermediária do greenstone belt Riacho de Santana foi datada pelo método U-Pb LA-ICPMS em zircão (Rodrigues et al., 2012). Sete cristais foram analisados, sendo que duas dessas análises forneceram resultados concordantes no diagrama 
concórdia, indicando a cristalização do metabasalto em $2218 \pm 18 \mathrm{Ma}(\mathrm{MSWD}=2,0)$. Em adição, as idades de zircões herdados variam entre 2,7 e 3,0 Ga, ratificando a hipótese de contaminação crustal (Rodrigues et al., informação oral). Contudo, cabe notar que zircões em rochas básicas usualmente são xenocristais, daí porque geralmente se busca analisar a badelleita por ser coeva à cristalização do líquido magmático. Em suma, os dados disponíveis apontam uma idade riaciana para o magmatismo da unidade intermediária deste greenstone belt, cuja gênese envolveu componentes arqueanos. Essa hipótese é consistente com a interpretação geoquímica formulada por Menezes Leal et al. (2008) conforme sugerido pelo comportamento dos ETR entre outras evidências. Cabe finalmente mencionar que uma determinação K-Ar (rocha total) em sericita xisto indicou idade mínima de $1718 \pm 33 \mathrm{Ma}$ (Brito Neves et al., 1980), mas com teor de potássio da sericita analisada muito baixo $(2,45 \%)$. Uma idade isocrônica preliminar Sm-Nd em rocha total com apenas 3 pontos $(3200 \pm$ $200 \mathrm{Ma})$ foi reportada para rochas metamáficas da unidade intermediária (metabasaltos) deste greenstone belt (e.g., Silveira e Garrido, 2000). Esse dado será aqui reavaliado com base nas características isotópicas dessas amostras.

\section{Batólito Guanambi}

As rochas granitoides intrusivas da região de estudo são representadas por corpos de composição sienítica e monzogranítica com granitos subordinados (batólito Guanambi), intrusivos nos complexos Gnáissico Migmatítico Riacho de Santana e Santa Isabel e greenstone belt Riacho de Santana, além de correspondentes vulcânicos caracterizados por sills e diques de ocorrência local (Paim et al., 1999; Rosa, 1999). Alguns desses plútons estão lineados e/ou foliados, especialmente nas proximidades de zonas de cisalhamentos regionais.

No âmbito do BGO, exemplos do magmatismo paleoproterozoico são comuns, caracterizados por intrusões múltiplas e tardias de rochas graníticas, sieníticas e monzoníticas (Rosa, 1999). Estas apresentam xenólitos de gnaisse, rocha básica e metavulcanossedimentar (Figura 5D). Em termos texturais, o batólito Guanambi é constituído por rochas faneríticas médias a grossas, usualmente porfiríticas. Em adição, variedades efusivas coevas (e.g., riolitos) são descritas na literatura (Silveira e Garrido, 2000). As idades isocrônicas $\mathrm{Rb} / \mathrm{Sr}$ em rocha total para essas intrusivas situam-se entre $1850 \pm 60$ e $2080 \pm 70 \mathrm{Ma}$, com razões iniciais entre 0,705 e 0,709 que sugerem uma contaminação por material preexistente durante sua colocação na crosta (Jardim de Sá et al., 1976; Mascarenhas e Garcia, 1989; Rosa, 1999).

A idade U-Pb de cristalização do batólito Guanambi (monzonitos e sienitos) é de $2054 \pm 8$ Ma segundo Rosa (1999). Tanto os dados $\mathrm{Rb} / \mathrm{Sr}$ anteriores, bem como os dos diagramas concórdia $\mathrm{U} / \mathrm{Pb}$ em diferentes plútons com idades (em concentrados de zircões) entre $2076 \pm 18$ e $2024 \pm 2 \mathrm{Ma}$, registram o intervalo temporal para a cristalização do batólito. Por outro lado, as idades aparentes K-Ar em hornblenda $(1947 \pm 58 \mathrm{Ma})$ e biotita $(1927 \pm 46$ a $527 \pm 20 \mathrm{Ma})$ refletem a longa história tectonotermal regional.

Os valores negativos de $\varepsilon_{\mathrm{Nd}(2,0 \mathrm{Ga})}(-7,4,-10,6)$ e razões iniciais ${ }^{87} \mathrm{Sr}^{86} \mathrm{Sr}_{\mathrm{i}(2,0 \text { Ga) }}$ entre $0,705-0,706$ (Rosa, 1999) e 0,705 - 0,709 (Mascarenhas e Garcia, 1989; Brito Neves et al., 1980), além dos dados geoquímicos, corroboram a hipótese de dois magmas geradores deste batólito: (i) um de natureza básica potássica, controlada principalmente pela cristalização da apatita, zircão, ilmenita e clinopiroxênio, sob baixa $\mathrm{fO}_{2}$ e alta $\mathrm{PH}_{2} \mathrm{O}$. As altas razões de Al/Ti nos clinopiroxênios atestam pressões, em torno de $10 \mathrm{kbar}$ (Rosa, 1999), compatíveis com uma geração em profundidades próximas à base da crosta continental e/ou na parte superior do manto; (ii) outro ultrapotássico $\left(\mathrm{K}_{2} \mathrm{O} / \mathrm{Na}_{2} \mathrm{O}>2\right.$ e 2 a $4 \% \mathrm{Mg}$ ), característico do estágio magmático tardio, controlado pela cristalização do anfibólio e marcado pela formação do feldspato, em condições hipersolvus. Os anfibólios e plagioclásios fornecem para este estágio pressões entre 2,2 e 4,4 kbar, respectivamente, e temperaturas em torno de $850^{\circ} \mathrm{C}$, posicionando essa cristalização na parte mediana da crosta $(9-15 \mathrm{~km})$ (Rosa, 1999). Em termos geoquímicos, as amostras do batólito Guanambi são saturadas a supersaturadas em sílica, alcalinas e metaluminosas. O padrão fracionado de ETR sem anomalia de Eu ou com incipiente anomalia desse elemento é compatível com fracionamento do plagioclásio na fonte. Segundo Rosa (1999), as rochas deste batólito foram formadas a partir de processo de cristalização fracionada de um magma lamprofírico em ambiente pós-colisional.

\section{MÉTODOS ANALÍTICOS E ESTRATÉGIA DE TRABALHO}

Para a caracterização geocronológica do BGO, foram selecionadas quatro unidades litoestratigráficas. Destas, foram selecionados o Complexo Gnáissico Migmatítico Riacho de Santana para análises U-Pb Laser Ablation e Sm-Nd, o Complexo Santa Isabel (métodos U-Pb Laser Ablation, $\mathrm{Pb}-\mathrm{Pb}$ evaporação em zircão e $\mathrm{Sm}-\mathrm{Nd}$ ), rochas vulcânicas do greenstone belt Riacho de Santana (método Sm-Nd) e uma rocha subvulcânica félsica representante do batólito Guanambi (métodos $\mathrm{Pb}-\mathrm{Pb}$ evaporação em zircão e Sm-Nd).

As amostras selecionadas para o método U-Pb Laser Ablation foram analisadas no Laboratório de Geoquímica Isotópica do Departamento de Geologia da Universidade do Texas, Estados Unidos (análises realizadas por L. R. Bastos Leal). Os zircões foram analisados utilizando-se 


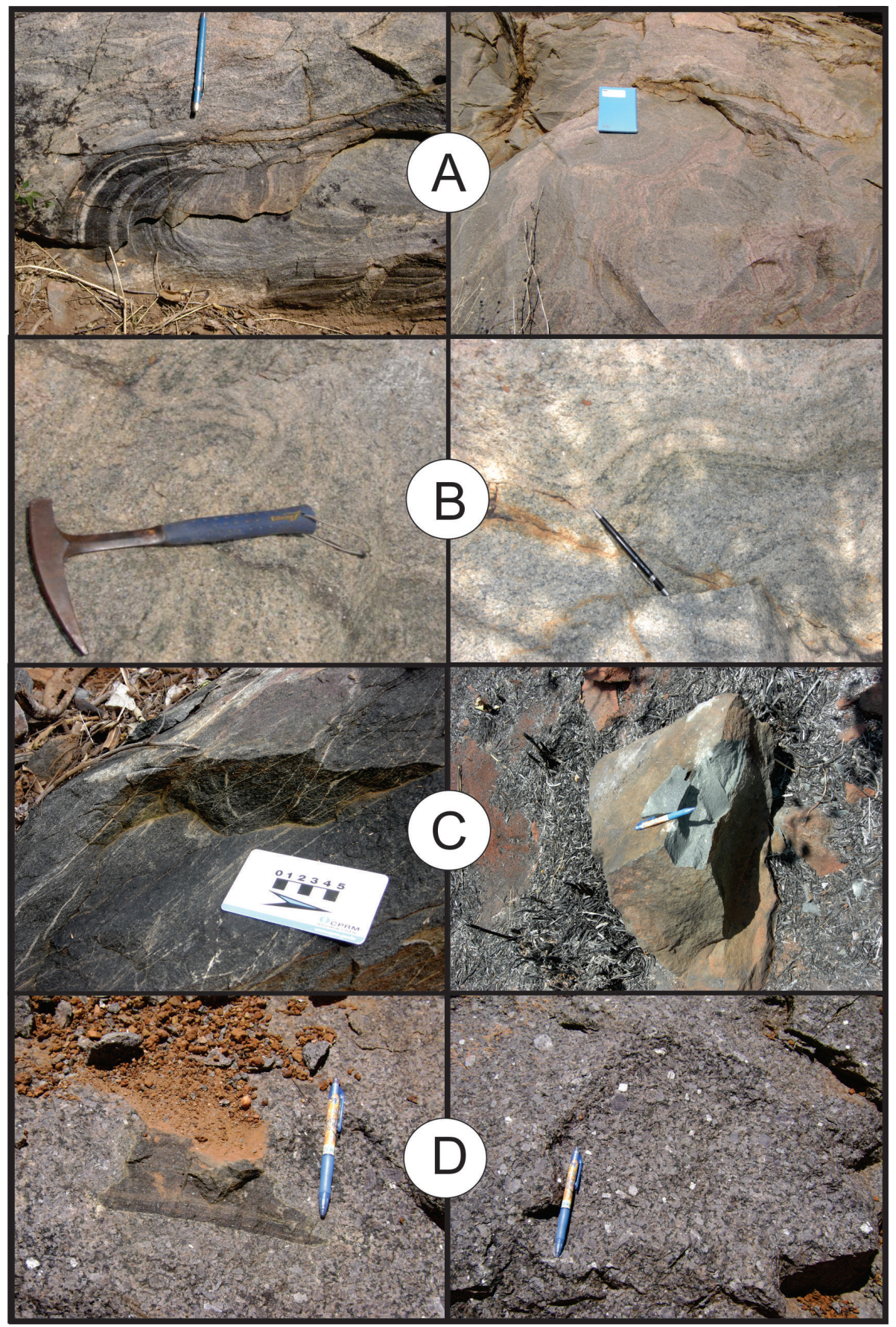

Figura 5. Feições de afloramento das rochas da unidade do Bloco Gavião Oeste. (A) Complexo Gnáissico Migmatítico Riacho de Santana; ortognaisse mostrando enclaves dobrados concordantemente com o bandamento da rocha encaixante (foto à esquerda). A fotografia da direita ilustra uma rocha tonalítica com feições de migmatização e porções feldspáticas no leucossoma. Esses afloramentos são encontrados em forma de lajedo localizados a norte da cidade de Riacho de Santana. (B) Complexo Santa Isabel; as fotografias representam granulitos charnockíticos com migmatização. O leucossoma é composto por plagioclásio e k-feldspato com proporções semelhantes. A rocha encontra-se bastante deformada com dobras parasíticas. Os afloramentos estão situados a sudoeste da cidade de Riacho de Santana. (C) Greenstone belt Riacho de Santana. As fotos mostram metabasaltos com vênulas de plagioclásio (foto à esquerda), enquanto no outro afloramento a rocha apresenta-se homogênea e fina. Os afloramentos ocorrem como blocos rolados ou pequenos lajedos situados a noroeste da cidade de Riacho de Santana. (D) Batólito Guanambi; esse afloramento é representado por um alcali-feldspato sienito grosso, com pouca matriz, textura porfirítica e cristais euédricos de feldspatos potássicos. Xenólitos de rochas basálticas também ocorrem como ilustrado na foto. 
o LA-MC-ICPMS. Os procedimentos analíticos envolvem a determinação das razões isotópicas ${ }^{206} \mathrm{~Pb} /{ }^{238} \mathrm{U}$, ${ }^{207} \mathrm{~Pb} /{ }^{235} \mathrm{U}$ e ${ }^{207} \mathrm{~Pb} / 206 \mathrm{~Pb}$, com correções de $\mathrm{Pb}$ comum conforme Stacey e Kramers (1975). A discordância foi calculada com base nas idades ${ }^{206} \mathrm{~Pb} /{ }^{238} \mathrm{U}$ e ${ }^{207} \mathrm{~Pb} /{ }^{235} \mathrm{U}$. Os erros analíticos foram calculados com $2 \sigma$ de desvio padrão da média. O procedimento analítico consiste na projeção de um laser com alta precisão "jackhammer" (a energia é concentrada em uma distância focal), o qual atinge o zircão em uma região previamente designada. Infelizmente, imagens de catodoluminescência dos grãos analisados pelo método U-Pb Laser Ablation não foram realizadas de modo a permitir inferências sobre a morfologia e complexidade interna dos zircões.

As análises ${ }^{207} \mathrm{~Pb} /{ }^{206} \mathrm{~Pb}$ evaporação de zircão foram realizadas no Laboratório de Geologia Isotópica da Universidade Federal do Pará (Pará-Iso), utilizando-se um espectrômetro de massa Finnigan Mat 262 (Thermo Scientific). $O$ procedimento consiste em depositar o zircão em um filamento de rênio e realizar três etapas de evaporação nas temperaturas de $1.450,1.500$ e $1.550^{\circ} \mathrm{C}$. As razões ${ }^{207} \mathrm{~Pb} /{ }^{206} \mathrm{~Pb}$ adquiridas nas altas temperaturas são, normalmente, as utilizadas para o cálculo da idade aparente. A idade ${ }^{207} \mathrm{~Pb} /{ }^{206} \mathrm{~Pb}$ calculada é corrigida para $\mathrm{Pb}$ comum com base na razão ${ }^{206} \mathrm{~Pb} /{ }^{204} \mathrm{~Pb}$, a qual é determinada a partir da média ponderada das idades dos cristais analisados e os erros analíticos são apresentados com $2 \sigma$ de desvio padrão da média. Segundo procedimento convencional para obtenção das idades por evaporação de zircão (Gaudette et al., 1998), as razões ${ }^{207} \mathrm{~Pb} / 206 \mathrm{~Pb}$ são representadas em um diagrama binário (número de blocos versus idade).

Doze análises $\mathrm{Sm} / \mathrm{Nd}$ em rocha total em amostras das unidades anteriormente mencionadas foram realizadas no Centro de Pesquisas Geocronológicas da Universidade de São Paulo (CPGeo-USP), conforme procedimentos descritos em Sato et al. (1995). Aproximadamente 0,10 g de pó de rocha foi dissolvida nos ácidos $\mathrm{HNO}_{3}, \mathrm{HF}$ e $\mathrm{HCl}$ e, para separação primária do $\mathrm{Sm}$ e $\mathrm{Nd}$, foi utilizada uma resina de troca iônica, seguida por uma coluna revestida de teflon. As razões isotópicas foram medidas no espectrômetro VG354 multicoletor e os erros foram calculados para $2 \sigma$. Os cálculos das razões isotópicas foram realizados usando-se as constantes propostas por Michard et al. (1985) e as idades modelo $\mathrm{Sm} / \mathrm{Nd}$ foram calculadas por meio do modelo De Paolo (1988) e De Paolo et al. (1991). Os cálculos de $f_{\mathrm{Sm} / \mathrm{Nd}}$ seguiram a proposta de Bennett e De Paolo (1987).

Dados prévios $\mathrm{Rb} / \mathrm{Sr}$ em rocha total foram reavaliados com base na distribuição geográfica, conforme cartografia geológica regional de Silveira e Garrido (2000), de modo a dar mais representatividade às isócronas de referência dos complexos do embasamento. O Anexo 1 apresenta a listagem completa dos dados da literatura, agrupados de acordo com os diagramas isocrônicos, considerados como representativos dos complexos Gnáissico Migmatítico Riacho de Santana e Santa Isabel, em conformidade com a cartografia aqui adotada.

A idade U/Pb do Complexo Santa Isabel (Rosa, 1999) foi recalculada por meio de uma nova seleção dos dados analíticos com erros nas razões $\left({ }^{207} \mathrm{~Pb} /{ }^{235} \mathrm{U}\right.$ e $\left.{ }^{206} \mathrm{~Pb} /{ }^{238} \mathrm{U}\right)$ entre 0,31 e $0,52 \%$, de modo a se obter um MSWD estatisticamente aceitável para a discórdia. Quanto aos dados prévios Sm/Nd do greenstone belt Riacho de Santana (Silveira e Garrido, 2000), foi realizada uma reinterpretação com base na avaliação dessa sistemática isotópica, comparativamente a parâmetros de fracionamento crustal da literatura (De Paolo, 1988; Bennett e De Paolo, 1987).

O programa Isoplot/EX (Ludwig, 2000) foi utilizado para o cálculo das idades $\mathrm{U} / \mathrm{Pb}, \mathrm{Rb} / \mathrm{Sr}$ e razões iniciais. Os resultados estão sumarizados nas Tabelas 1 a 4 e no Anexo 1. As amostras datadas pelos diferentes métodos não são representantes dos afloramentos da Figura 5.

\section{RESULTADOS E DISCUSSÃO}

\section{Complexo Gnáissico Migmatítico Riacho de Santana}

$\mathrm{O}$ afloramento deste complexo, datado pelo método $\mathrm{U}-\mathrm{Pb}$ (Laser Ablation), corresponde a um ortognaisse tonalítico, cuja mineralogia principal é constituída por plagioclásio, quartzo, microclina, hornblenda e biotita. Titanita, minerais opacos, apatita e zircão formam as fases minerais subordinadas. Processos de alteração hidrotermal também estão presentes, como saussuritização e sericitização do plagioclásio. As texturas identificadas são a granoblástica e a lepidoblástica. Em adição, este complexo é formado por gnaisses de composição granítica (monzogranítica a granodiorítica), cuja mineralogia principal é caracterizada por plagioclásio, feldspato alcalino, quartzo, hornblenda e biotita. A Figura 5A apresenta feições típicas de afloramento desta unidade, representado por rochas que afloram na forma de grandes blocos rolados, apresentam coloração variando de cinza-clara a cinza-rosada, com granulação média.

As datações pelo método U-Pb Laser Ablation realizadas em um ortognaisse totalizaram 19 grãos de zircão (amostra RS-07). As análises apresentam forte discordância no diagrama concórdia, com um intercepto superior claramente sem significado (Figura 6). Os pontos analíticos apresentam erros muito elevados, nas razões $\mathrm{U}$ e $\mathrm{Pb}$, dificultando a interpretação dos dados analíticos (Tabela 1). Os dados concentram-se no diagrama próximo ao intercepto inferior com idade de $656 \pm 100$ Ma, sugerindo perda episódica e/ou contínua de $\mathrm{Pb}$ no Neoproterozoico. Esse processo estaria relacionado à influência do evento marginal ao Cráton (faixas brasilianas), de maneira análoga ao detectado 
Tabela 1. Análises U/Pb em zircão do Complexo Gnáissico Migmatítico Riacho de Santana (amostra RS-07).

\begin{tabular}{lccrccc}
\hline Grão & ${ }^{206} \mathrm{~Pb}$ & ${ }^{206} \mathrm{~Pb} /{ }^{238} \mathrm{U}^{*}$ & \multicolumn{1}{c}{${ }^{207} \mathrm{~Pb} /{ }^{235} \mathrm{U}^{*}$} & ${ }^{207} \mathrm{~Pb} /{ }^{206} \mathrm{~Pb}^{*}$ & $\begin{array}{c}{ }^{207} \mathrm{~Pb} /{ }^{206} \mathrm{~Pb}^{*} \\
(\mathrm{Ma})\end{array}$ & $\begin{array}{c}{ }^{206} \mathrm{~Pb} /{ }^{238} \mathrm{U} \\
(\mathrm{Ma})\end{array}$ \\
\hline RS 07-12 & 0,0390 & $0,0809 \pm 0,0195$ & $1,895 \pm 0,082$ & $0,1699 \pm 0,0089$ & $2557 \pm 88$ & $502 \pm 116$ \\
RS 07-13 & 0,0150 & $0,1841 \pm 0,0157$ & $3,398 \pm 0,232$ & $0,1338 \pm 0,0071$ & $2149 \pm 93$ & $1090 \pm 86$ \\
RS 07-14 & 0,0357 & $0,2104 \pm 0,0306$ & $4,518 \pm 0,232$ & $0,1557 \pm 0,0062$ & $2410 \pm 68$ & $1231 \pm 163$ \\
RS07 -15 & 0,0417 & $0,2339 \pm 0,0554$ & $11,454 \pm 0,767$ & $0,3552 \pm 0,0154$ & $3729 \pm 66$ & $1355 \pm 290$ \\
RS 07-16 & 0,0240 & $0,2175 \pm 0,0256$ & $7,991 \pm 0,559$ & $0,2665 \pm 0,0128$ & $3286 \pm 75$ & $1268 \pm 135$ \\
RS 07-17 & 0,0245 & $0,1679 \pm 0,0352$ & $4832 \pm 0,542$ & $0,2088 \pm 0,0200$ & $2896 \pm 156$ & $1000 \pm 194$ \\
RS 07-18 & 0,0295 & $0,1467 \pm 0,0165$ & $4,521 \pm 0,407$ & $0,2235 \pm 0,0191$ & $3006 \pm 137$ & $883 \pm 93$ \\
RS 07-19 & 0,0524 & $0,2198 \pm 0,0190$ & $8,095 \pm 0,557$ & $0,2672 \pm 0,0127$ & $3289 \pm 75$ & $1281 \pm 101$ \\
RS 07-20 & 0,0347 & $0,2131 \pm 0,1099$ & $7,433 \pm 0,440$ & $0,2529 \pm 0,0107$ & $3203 \pm 67$ & $1246 \pm 584$ \\
RS 07-28 & 0,0541 & $0,1714 \pm 0,0292$ & $4,647 \pm 0,257$ & $0,1966 \pm 0,0090$ & $2799 \pm 75$ & $1020 \pm 161$ \\
RS 07-29 & 0,0593 & $0,1854 \pm 0,0826$ & $3,994 \pm 0,190$ & $0,1562 \pm 0,0065$ & $2415 \pm 71$ & $1096 \pm 449$ \\
RS 07-30 & 0,0431 & $0,1649 \pm 0,0506$ & $4,685 \pm 0,438$ & $0,2061 \pm 0,0150$ & $2875 \pm 118$ & $984 \pm 280$ \\
RS 07-31 & 0,0207 & $0,1309 \pm 0,0293$ & $4,589 \pm 0,255$ & $0,2542 \pm 0,0129$ & $3211 \pm 80$ & $793 \pm 167$ \\
RS 07-33 & 0,0234 & $0,1303 \pm 0,0164$ & $3,406 \pm 0,187$ & $0,1896 \pm 0,0103$ & $2739 \pm 90$ & $789 \pm 94$ \\
RS 07-34 & 0,0279 & $0,1172 \pm 0,0396$ & $4,586 \pm 0,432$ & $0,2837 \pm 0,0244$ & $3383 \pm 134$ & $715 \pm 228$ \\
RS 07-35 & 0,0032 & $0,3312 \pm 0,0201$ & $16,164 \pm 1,140$ & $0,3540 \pm 0,0141$ & $3724 \pm 60$ & $1844 \pm 98$ \\
RS 07-37 & 0,0319 & $0,1242 \pm 0,0558$ & $3,729 \pm 0,206$ & $0,2177 \pm 0,0116$ & $2964 \pm 86$ & $755 \pm 320$ \\
RS 07-38 & 0,0213 & $0,2486 \pm 0,0369$ & $9,837 \pm 0,617$ & $0,2870 \pm 0,0119$ & $3401 \pm 65$ & $1431 \pm 191$ \\
RS 07-40 & 0,1013 & $0,1643 \pm 0,0152$ & $4,753 \pm 0,226$ & $0,2098 \pm 0,0089$ & $2904 \pm 69$ & $981 \pm 84$ \\
\hline
\end{tabular}

*Amostra com distúrbio isotópico (ver texto para detalhes).

Tabela 2. Dados isotópicos Sm/Nd em unidades litoestratigráficas do Bloco Gavião Oeste.

\begin{tabular}{|c|c|c|c|c|c|c|c|c|c|c|}
\hline Unidades & Amostra & $\begin{array}{c}\mathrm{Sm} \\
(\mathrm{ppm})\end{array}$ & $\begin{array}{c}\mathrm{Nd} \\
(\mathrm{ppm})\end{array}$ & $\begin{array}{c}f \mathrm{Sm} / \\
\mathrm{Nd}\end{array}$ & ${ }^{147} \mathrm{Sm} /{ }^{144} \mathrm{Nd}$ & ${ }^{143} \mathrm{Nd} /{ }^{144} \mathrm{Nd}$ & $\begin{array}{l}\mathrm{T}_{\mathrm{DM}} \\
(\mathrm{Ga}) \\
\end{array}$ & $\begin{array}{c}\text { Idade } \\
\text { (Ga) }\end{array}$ & $\varepsilon_{\mathrm{Ndt}}$ & $\varepsilon_{\mathrm{Nd} 0}$ \\
\hline \multirow{2}{*}{$\begin{array}{l}\text { Complexo } \\
\text { Gnáissico } \\
\text { Migmatítico } \\
\text { Riacho de } \\
\text { Santana } \\
\end{array}$} & BR-WP-12A & 5,4 & 41,0 & $-0,60$ & $\begin{array}{c}0,079880 \pm \\
0,000044\end{array}$ & $\begin{array}{c}0,510430 \pm \\
0,000021\end{array}$ & 3,0 & - & - & $-43,1$ \\
\hline & BR-WP-12B & 4,0 & 25,3 & $-0,52$ & $0,0950 \pm 0,0003$ & $\begin{array}{c}0,5100607 \pm \\
0,0000160\end{array}$ & 3,9 & 3,6 & $-3,5$ & $-50,3$ \\
\hline \multirow{4}{*}{$\begin{array}{l}\text { Complexo } \\
\text { Santa Isabel }\end{array}$} & BR-09A & 2,7 & 17,9 & $-0,54$ & $0,0896 \pm 0,0003$ & $\begin{array}{c}0,510396 \pm \\
0,000040\end{array}$ & 3,3 & 2,9 & $-4,7$ & $-43,7$ \\
\hline & BR-12A A22 & 2,7 & 18,5 & $-0,54$ & $0,0909 \pm 0,0003$ & $\begin{array}{c}0,510600 \pm \\
0,000014\end{array}$ & 3,1 & 2,9 & 0,3 & $-40,0$ \\
\hline & BR-12B A22 & 3,9 & 25,3 & $-0,52$ & $0,0950 \pm 0,0003$ & $\begin{array}{c}0,510607 \pm \\
0,000016\end{array}$ & 3,2 & 2,9 & $-1,3$ & $-39,6$ \\
\hline & BR-12B A22 & 3,9 & 24,9 & $-0,52$ & $0,0941 \pm 0,0003$ & $\begin{array}{c}0,510630 \pm \\
0,000012\end{array}$ & 3,1 & 2,9 & $-1,4$ & $-39,2$ \\
\hline \multirow{3}{*}{$\begin{array}{l}\text { Unidade } \\
\text { Intermediária } \\
\text { do } \\
\text { Greenstone } \\
\text { Belt Riacho } \\
\text { de Santana } \\
\end{array}$} & WPR-116 & 2,6 & 8,1 & $-0,01$ & $0,1942 \pm 0,0001$ & $\begin{array}{c}0,512746 \pm \\
0,000035\end{array}$ & 2,3 & 2,2 & $+2,8$ & $+2,1$ \\
\hline & WPR-217* & 4,2 & 21,1 & $-0,39$ & $0,1196 \pm 0,0001$ & $\begin{array}{c}0,511168 \pm \\
0,000036\end{array}$ & - & - & - & $-28,7$ \\
\hline & WPR-320 & 3,2 & 11,5 & $-0,14$ & $0,1689 \pm 0,0001$ & $\begin{array}{c}0,512284 \pm \\
0,000570\end{array}$ & 2,6 & 2,2 & $+1,1$ & $-7,9$ \\
\hline \multirow{3}{*}{$\begin{array}{l}\text { Batólito } \\
\text { Guanambi }\end{array}$} & WPR-211 & 2,3 & 10,8 & $-0,34$ & $0,1297 \pm 0.0005$ & $\begin{array}{c}0,511535 \pm \\
0,000013\end{array}$ & 2,7 & 2,0 & $-4,2$ & $-21,5$ \\
\hline & WPR-344 & 6,4 & 39,5 & $-0,50$ & $0,0676 \pm 0,0002$ & $\begin{array}{c}0,511128 \pm \\
0,000012\end{array}$ & 2,6 & 2,0 & $-4,7$ & $-30,0$ \\
\hline & WPR-208 & 16,3 & 112,3 & $-0,55$ & $\begin{array}{c}0,088639 \pm \\
0,000115\end{array}$ & $\begin{array}{c}0,510805 \pm \\
0,000039\end{array}$ & 2,7 & 2,0 & $-8,0$ & $-35,8$ \\
\hline
\end{tabular}

*Amostra com distúrbio isotópico (ver texto para detalhes).

$\mathrm{T}_{\mathrm{DM}}$ : idade modelo. 
Tabela 3. Dados isotópicos $\mathrm{U} / \mathrm{Pb}$ Laser Ablation em zircão para rocha granulítica do Complexo Santa Isabel (amostra BR-09).

\begin{tabular}{lcccccc}
\hline Grão & $\mathrm{Pb}_{\text {comum }}$ & ${ }^{206} \mathrm{~Pb} /{ }^{238} \mathrm{U}^{*}$ & ${ }^{207} \mathrm{~Pb} /{ }^{235} \mathrm{U}^{*}$ & ${ }^{207} \mathrm{~Pb} /{ }^{206} \mathrm{~Pb}^{*}$ & $\begin{array}{c}{ }^{207} \mathrm{~Pb} /{ }^{206} \mathrm{~Pb}^{*} \\
(\mathrm{Ma})\end{array}$ & $\begin{array}{c}{ }^{206} \mathrm{~Pb} /{ }^{238} \mathrm{U} \\
(\mathrm{Ma})\end{array}$ \\
\hline BR09-12 & 0,0473 & $0,1770 \pm 0,0140$ & $3,700 \pm 0,118$ & $0,1516 \pm 0,0046$ & $2364 \pm 51$ & $1050 \pm 77$ \\
BR09-13 & 0,0358 & $0,3013 \pm 0,0562$ & $8,506 \pm 0,324$ & $0,2048 \pm 0,0057$ & $2865 \pm 45$ & $1698 \pm 278$ \\
BR09-14 & 0,0477 & $0,1768 \pm 0,0157$ & $4,400 \pm 0,184$ & $0,1805 \pm 0,0059$ & $2658 \pm 54$ & $1049 \pm 86$ \\
BR09-15 & 0,0344 & $0,1675 \pm 0,0203$ & $3,121 \pm 0,098$ & $0,1351 \pm 0,0044$ & $2166 \pm 56$ & $998 \pm 112$ \\
BR09-16 & 0,0346 & $0,1755 \pm 0,0176$ & $3,917 \pm 0,120$ & $0,1619 \pm 0,0047$ & $2475 \pm 49$ & $1042 \pm 96$ \\
BR09-17 & 0,0413 & $0,2247 \pm 0,0540$ & $5,943 \pm 0,685$ & $0,1918 \pm 0,0167$ & $2758 \pm 143$ & $1307 \pm 284$ \\
BR09-19 & 0,1377 & $0,1611 \pm 0,0269$ & $2,750 \pm 0,109$ & $0,1238 \pm 0,0050$ & $2012 \pm 72$ & $963 \pm 149$ \\
BR09-27 & 0,0309 & $0,1774 \pm 0,0258$ & $4,277 \pm 0,202$ & $0,1749 \pm 0,0074$ & $2605 \pm 71$ & $1053 \pm 141$ \\
BR09-30 & 0,0252 & $0,2195 \pm 0,0205$ & $5,897 \pm 0,226$ & $0,1949 \pm 0,0058$ & $2784 \pm 49$ & $1279 \pm 108$ \\
BR09-31 & 0,0415 & $0,1842 \pm 0,0284$ & $4,919 \pm 0,197$ & $0,1937 \pm 0,0057$ & $2774 \pm 48$ & $1090 \pm 154$ \\
BR09-32 & 0,0694 & $0,1276 \pm 0,0047$ & $1,950 \pm 0,056$ & $0,1108 \pm 0,0039$ & $1813 \pm 64$ & $774 \pm 27$ \\
BR09-33 & 0,0582 & $0,1781 \pm 0,0137$ & $4,249 \pm 0,135$ & $0,1730 \pm 0,0051$ & $2587 \pm 49$ & $1057 \pm 75$ \\
BR09-34 & 0,0839 & $0,1836 \pm 0,0248$ & $4,206 \pm 0,170$ & $0,1662 \pm 0,0048$ & $2519 \pm 49$ & $1086 \pm 135$ \\
BR09-36 & 0,0147 & $0,1546 \pm 0,0193$ & $2,647 \pm 0,093$ & $0,1242 \pm 0,0048$ & $2017 \pm 68$ & $927 \pm 108$ \\
BR09-37 & 0,0529 & $0,1295 \pm 0,0111$ & $2,319 \pm 0,082$ & $0,1298 \pm 0,0053$ & $2096 \pm 71$ & $785 \pm 63$ \\
BR09-38 & 0,0389 & $0,1528 \pm 0,0133$ & $3,318 \pm 0,097$ & $0,1575 \pm 0,0051$ & $2429 \pm 54$ & $917 \pm 74$ \\
BR09-39 & 0,0205 & $0,1780 \pm 0,0372$ & $4,315 \pm 0,159$ & $0,1758 \pm 0,0060$ & $2614 \pm 57$ & $1056 \pm 204$ \\
BR09-40 & 0,0387 & $0,1786 \pm 0,0126$ & $4,071 \pm 0,148$ & $0,1653 \pm 0,0048$ & $2511 \pm 49$ & $1059 \pm 69$ \\
BR09-41 & 0,0451 & $0,2451 \pm 0,0196$ & $6,136 \pm 0,233$ & $0,1815 \pm 0,0052$ & $2667 \pm 48$ & $1413 \pm 101$ \\
\hline
\end{tabular}

*Amostra com distúrbio isotópico (ver texto para detalhes).

Tabela 4. Dados isotópicos ${ }^{207} \mathrm{~Pb} /{ }^{206} \mathrm{~Pb}$ em zircões.

\begin{tabular}{lccc}
\hline Zircão & $\mathbf{N}^{\circ}$ de Blocos & ${ }^{207} \mathrm{~Pb} /{ }^{206} \mathrm{~Pb}( \pm \mathbf{2} \sigma)$ & Idade $(\mathbf{M a})$ \\
\hline Complexo Santa Isabel & 40 & & \\
RS-111/7 & 08 & $0,12036 \pm 0,0039$ & $1961 \pm 6$ \\
RS-111/10 & 06 & $0,12059 \pm 0,0171$ & $1965 \pm 25$ \\
RS-111/11 & 20 & $0,12095 \pm 0,0182$ & $1970 \pm 27$ \\
RS-111/14 & 16 & $0,12104 \pm 0,0051$ & $1972 \pm 8$ \\
RS-111/15 & & & $1966 \pm 8$ \\
Batólito Guanambi & 7 & $0,12018 \pm 0,0019$ & \\
WPR-208-8 & 6 & $0,12541 \pm 0,0021$ & $1960 \pm 29$ \\
WPR-208-13 & 22 & $0,12332 \pm 0,0014$ & $2036 \pm 29$ \\
WPR-208-16 & 4 & $0,12100 \pm 0,0066$ & $1978 \pm 98$ \\
WPR-208-18 & & & \\
\hline
\end{tabular}

RS-111: metagranitoide do Complexo Santa Isabel; WPR-208: rocha subvulcânica do Batólito Guanambi. 
em compartimentos tectônicos adjacentes ao BGO (e.g., Corredor Paramirim, região central da Bahia - Cordani et al., 1985; Cruz, 2004; Alkmim e Martins-Neto, 2012).

Rosa (1999) já havia reportado uma idade U/Pb (Laser Ablation) para um ortognaisse interpretado então como pertencente ao Complexo Santa Isabel de $3352 \pm 231 /-290 \mathrm{Ma}$ (Rosa, 1999), com base em 14 análises. No entanto, essa rocha é aqui admitida como representante do Complexo Gnáissico Migmatítico Riacho de Santana, em função das coordenadas geográficas dessa amostra (informação escrita, M. L. Rosa, 2012) (ver Figura 2). Segundo Rosa (1999), os cristais datados de zircão apresentam hábito prismático, formas euedrais a subeuedrais, coloração castanho-escura avermelhada e contêm inclusões e fraturas. Devido aos altos erros analíticos dessas análises, foi recalculada, neste trabalho, a idade $\mathrm{U} / \mathrm{Pb}$ deste complexo, utilizando-se dez das análises de Rosa (1999). A idade do intercepto superior é de $3648 \pm 69 \mathrm{Ma}$ (Figura 7) com valor de MSWD =2,1, aqui considerado aceitável em termos estatísticos. Essa idade melhor reflete a época de cristalização desta rocha no Paleoarqueano, muito embora datações adicionais em outras rochas do Complexo Gnáissico Migmatítico Riacho de Santana sejam necessárias para detalhar a sua evolução crustal.

Duas análises Sm-Nd em rocha total de um mesmo afloramento de gnaisse deste complexo foram realizadas. Uma delas indicou valor de $f_{\mathrm{Sm} / \mathrm{Nd}}$ de $-0,52$, o que demonstra um fracionamento usual durante a diferenciação manto/crosta para as rochas de composição granítica (Bennett e De Paolo, 1987). A idade modelo $\mathrm{T}_{\mathrm{DM}}(3,9 \mathrm{Ga})$ e o respectivo valor negativo de $\varepsilon_{\mathrm{Nd}(3,6 \mathrm{Ga})}=-3,5$ (Tabela 2 ) sugerem um protólito paleoarqueano para a petrogênese da rocha. A outra idade $T_{D M}$ de 3,0 Ga implica tratar-se de material cuja gênese é distinta da outra amostra.

Conforme já relatado, a idade isocrônica $\mathrm{Rb}-\mathrm{Sr}$ reportada para o Complexo Gnáissico Migmatítico Riacho de

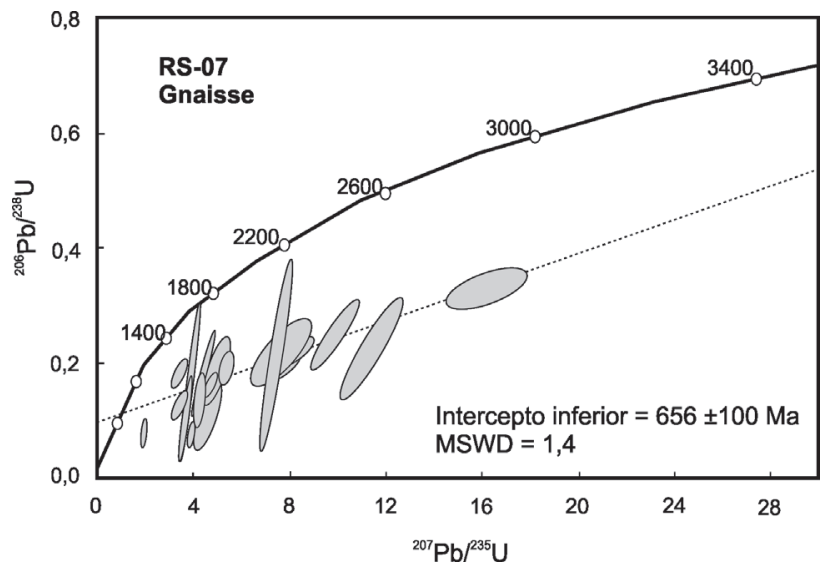

Figura 6. Diagrama Concórdia U/Pb Laser Ablation do complexo Gnáissico Migmatítico Riacho de Santana (amostra RS-07).
Santana de $2685 \pm 97$ Ma (Mascarenhas e Garcia, 1989) foi originalmente obtida com amostras então consideradas como embasamento (ver item anterior). Com base na cartografia aqui adotada, foi recalculada a idade com parte dessas amostras, cujos afloramentos, embora dispersos geograficamente, situam-se seguramente no Complexo Gnáissico Migmatítico. Entre as várias tentativas de cálculo isocrônico, o melhor alinhamento isotópico é constituído por quatro análises, que foram escolhidas por apresentarem um MSWD baixo, apesar do erro analítico elevado da idade $3247 \pm 120$ Ma e razão inicial de 0,7009 $\pm 0,0010-$ Anexo 1 e Figura 8).

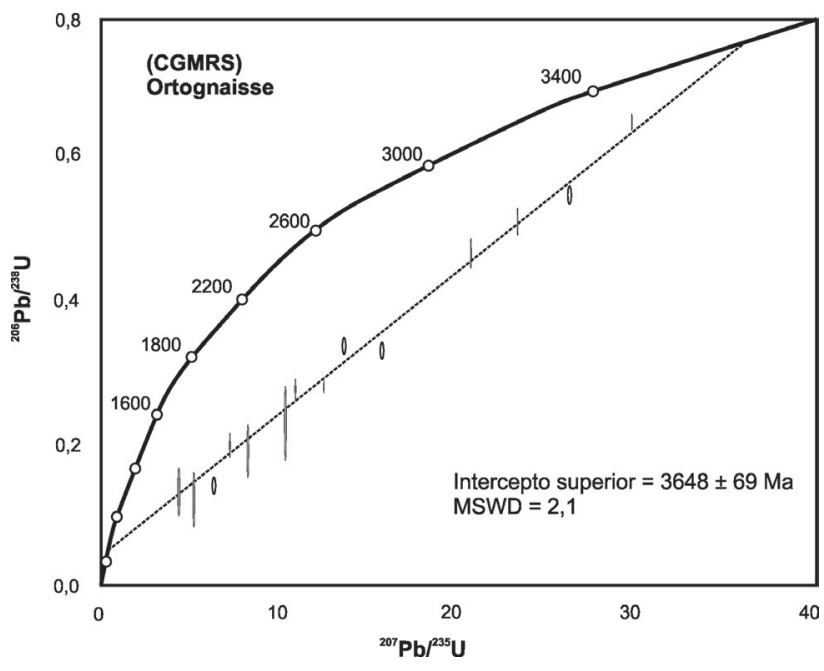

Fonte: reinterpretado de Rosa (1999).

Figura 7. Diagrama Concórdia U/Pb Laser Ablation Complexo Gnáissico Migmatítico Riacho de Santana (CGMRS). Símbolos vazios representam análises não utilizadas no cálculo da idade.

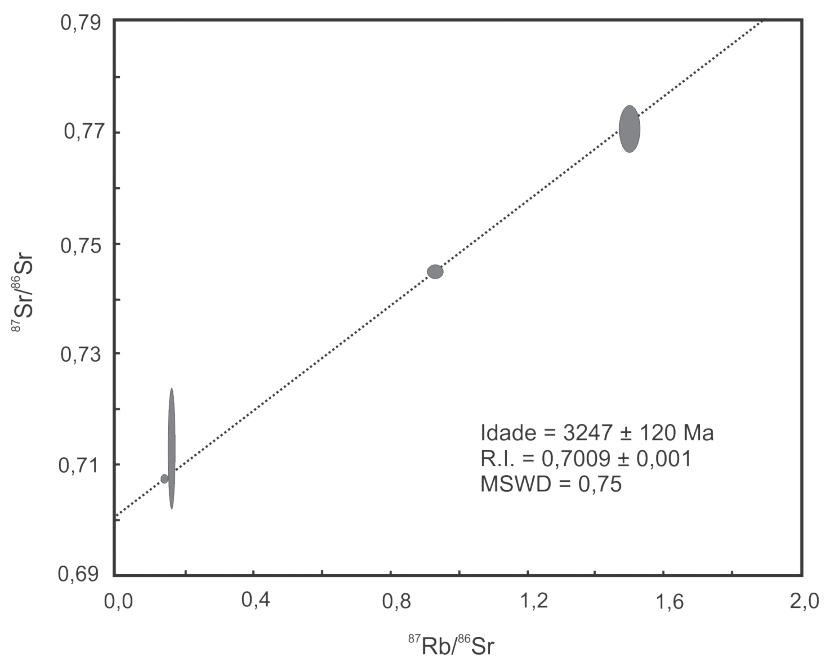

R.I.: razão inicial.

Figura 8. Isócrona $\mathrm{Rb} / \mathrm{Sr}$ referencial para rochas do Complexo Gnáissico Migmatítico Riacho de Santana. 


\section{Complexo Santa Isabel}

No Complexo Santa Isabel, foram realizadas análises pelos métodos $\mathrm{U}-\mathrm{Pb}$ Laser Ablation, $\mathrm{Pb}-\mathrm{Pb}$ evaporação em zircão e Sm-Nd em rocha total. Em adição, o acervo geocronológico $\mathrm{Rb}-\mathrm{Sr}$ foi tentativamente reinterpretado com base na cartografia de Silveira e Garrido (2000).

A Figura 5B apresenta as feições de campo de um migmatito deste complexo. Essa rocha é caracterizada por uma incipiente foliação com porções feldspáticas. Em algumas porções, estão bastante deformadas, com dobras parasíticas e apertadas, o que confirma que essas rochas foram retrabalhadas por eventos superpostos. As amostras analisadas pelo método $\mathrm{U} / \mathrm{Pb}$ Laser Ablation referem-se a um granulito deste complexo. Macroscopicamente, são isotrópicas com composições variando de ácida a básica. Os minerais essenciais são: plagioclásio, hiperstênio, diopsídio, biotita e hornblenda secundária.

Dezenove cristais de zircão (amostra BR-09) foram analisados. Os grãos apresentam hábito prismático, são alongados, com coloração castanha e fraturados. No diagrama concórdia, a maioria das análises posiciona-se abaixo da Curva Concórdia, com diferentes graus de discordância (Figura 9). Quinze dados (Tabela 3) alinham-se em uma discórdia com a idade do intercepto superior de $2954 \pm 100 \mathrm{Ma}(\mathrm{MSWD}=$ $5,7)$, considerada como a idade aproximada de cristalização dessa rocha. Quatro análises alinham-se em outra discórdia com intercepto superior de $2250 \pm 2 \mathrm{Ma}$ (MSWD = 1,9), havendo nesse conjunto um grão concordante. Esse fato sugere que o Complexo Santa Isabel foi retrabalhado nessa época. Uma vez que não há imagens de catodoluminescência para esses zircões, não é possível correlacionar tais idades com eventos metamórficos estabelecidos na literatura para este complexo.

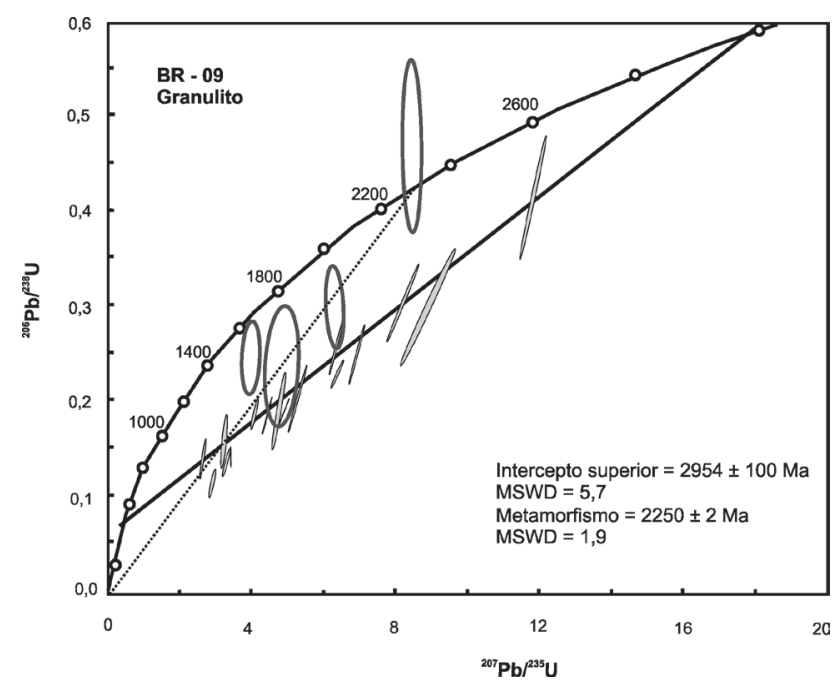

Figura 9. Diagrama Concórdia U/Pb Laser Ablation para rocha granulítica do Complexo Santa Isabel (amostra BR-09).
Ainda com relação ao Complexo Santa Isabel, foram feitas 15 análises pelo método $\mathrm{Pb} / \mathrm{Pb}$ por evaporação de zircão em metagranitoide - fácies anfibolito (amostra RS-111). Os cristais de zircão apresentam hábito prismático, são alongados, translúcidos, fraturados, arredondados nas extremidades, sendo que, em alguns casos, possuem faces bipiramidais e cor marrom (Figura 10). Dos 15 cristais selecionados e analisados, apenas 5 forneceram sinal de $\mathrm{Pb}$ adequado para as análises isotópicas. As idades ${ }^{207} \mathrm{~Pb} /{ }^{206} \mathrm{~Pb}$ variaram entre $1961 \pm 6$ e $1972 \pm 8 \mathrm{Ma}$, definindo a idade média de $1966 \pm 38 \mathrm{Ma}$ (Tabela 4 e Figura 11). Cabe notar que a idade mínima de $1972 \pm 8$ Ma sugere a existência de outro evento regional, o qual é significativamente mais jovem (dentro do erro) do que a colocação do batólito Guanambi (ver adiante).

Quatro análises $\mathrm{Sm}-\mathrm{Nd}$ em rochas gnáissicas do Complexo Santa Isabel indicaram valores de $f_{\mathrm{Sm} / \mathrm{Nd}}$ entre $-0,54$ e $-0,52$, compatíveis com valores de fracionamento médio para materiais crustais (Bennett e De Paolo, 1987). Os parâmetros petrogenéticos foram calculados com base na idade $\mathrm{U} / \mathrm{Pb}$ de $2,9 \mathrm{Ga}$, aqui considerada como uma estimativa para a idade de cristalização das rochas deste complexo (ver anteriormente). Os valores de $\varepsilon_{\mathrm{Nd}(2,9 \mathrm{Ga})}$ $(-4,7 ;-1,4 ;-1,3 ;+0,3)$ (Tabela 2$)$ e as idades modelo $\mathrm{T}_{\mathrm{DM}}$ (3,3 a 3,1 Ga) indicam acrescimento a partir de fontes homogêneas pouco contaminadas e/ou protólitos com curta vivência crustal.

A propósito do comportamento da sistemática $\mathrm{Rb} /$ Sr para o Complexo Santa Isabel, foi feita uma integração dos dados compilados da literatura (Figura $12 \mathrm{e}$ Anexo 1). A maioria das análises situa-se em um alinhamento com idade de $2748 \pm 100$ Ma com razão inicial de $0,7050 \pm 0,0033$ e MSWD $=3,1$. Embora sejam resultados imprecisos, essa idade poderia refletir um processo de re-homogeneização isotópica regional, sendo, portanto, posterior àquele determinado para o Complexo Gnáissico Migmatítico Riacho de Santana.

\section{Greenstone Belt Riacho de Santana}

Os metabasaltos da unidade intermediária deste greenstone belt, aqui estudados, são encontrados como blocos rolados e/ou in situ (e.g., cortes de estrada) e ainda como morros-testemunho. Trata-se de rochas homogêneas finas a médias. As feições texturais comuns são granoblástica e nematoblástica, tendo como minerais predominantes actinolita/tremolita (retrometamórfica), hornblenda e plagioclásio, compatível com uma paragênese da fácies xisto verde (e.g., Menezes Leal et al., 2008). Quartzo, clorita, epídoto e carbonatos são minerais secundários. Outras transformações secundárias são a saussuritização e a sericitização nos plagioclásios. Minerais opacos, zircão e titanita são os acessórios. 


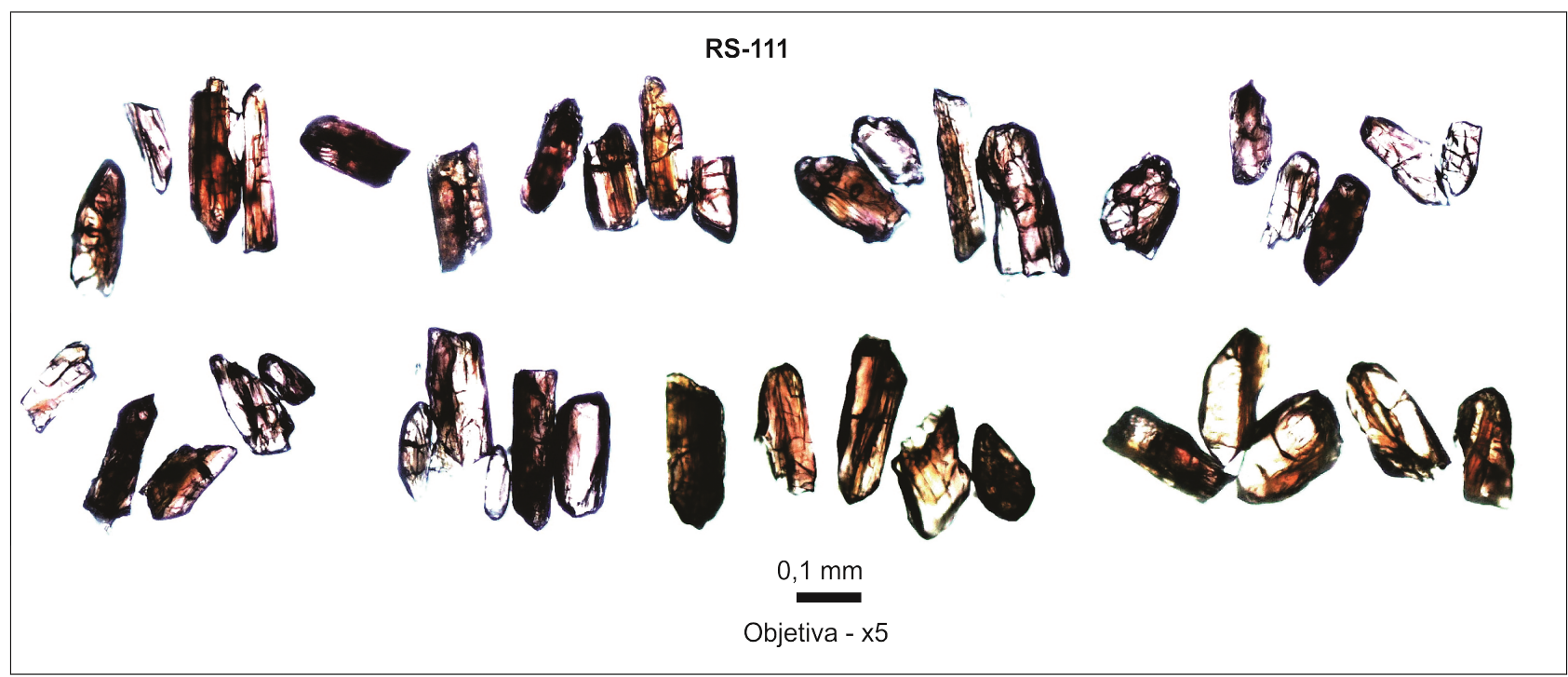

Figura 10. Fotografias dos zircões do metagranitoide (RS-111) do Complexo Santa Isabel.

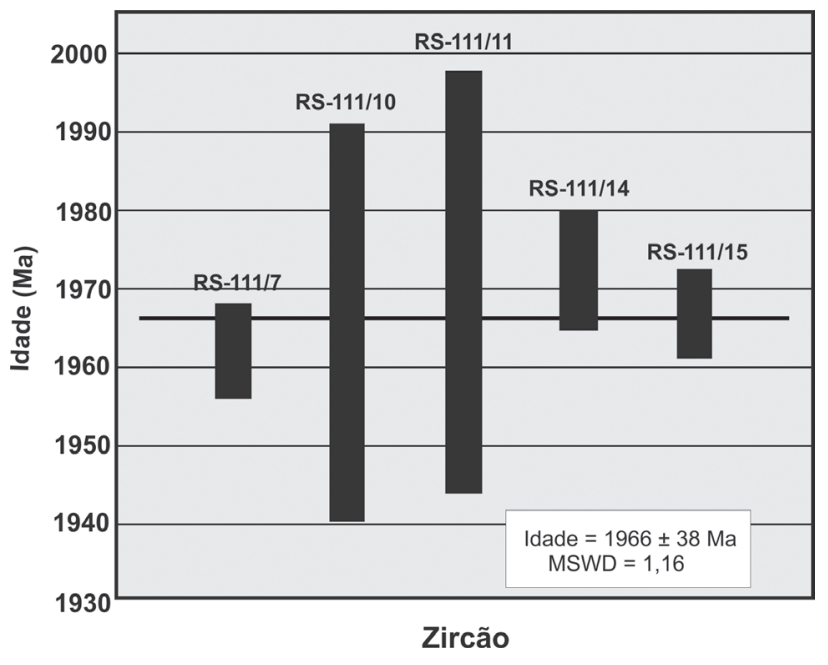

Figura 11. Diagrama idade (Ma) média dos zircões do metagranitoide RS-111 do Complexo Santa Isabel.

Apesar de essas rochas não apresentarem a mineralogia primária preservada, texturas ígneas reliquiares (ofítica e intergranular) podem ser observadas. Essas rochas encontram-se geralmente cisalhadas, foliadas, com vênulas de plagioclásio descontínuas e veios de quartzo por vezes boudinados (Figura 5C).

As três análises $\mathrm{Sm} / \mathrm{Nd}$ em rocha total para metabasaltos mostraram valores de $f_{\mathrm{Sm} / \mathrm{Nd}}$ distintos $(-0,01 ;-0,14$ e -0,39). Várias hipóteses podem ser aventadas no caso: (i) a variação revelaria processos distintos de contaminação crustal; (ii) petrogênese distinta dos materiais analisados; (iii) combinação de ambos os processos. Segundo Menezes Leal et al. (2008), o comportamento geoquímico de um conjunto de metabasaltos favorece o mecanismo de contaminação crustal (e.g., razões $\mathrm{Ba} / \mathrm{Zr}$, Ti/Y, Ba/Nb, Ti/Y, Nb/Y, Nb/Th

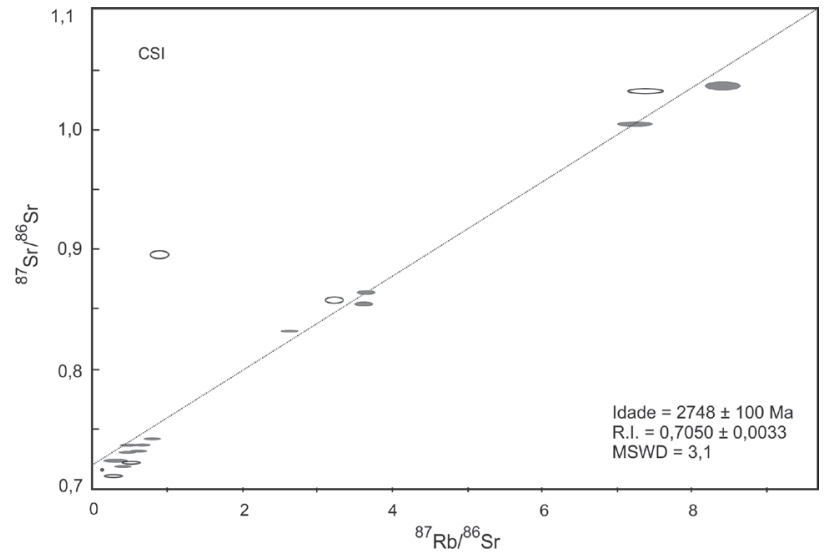

R.I.: razão inicial.

Figura 12. Isócrona $\mathrm{Rb} / \mathrm{Sr}$ de referência em rocha total para as rochas do Complexo Santa Isabel. Os símbolos vazios representam análises não utilizadas no cálculo da idade (os dados estão apresentados no Anexo 1).

e $\mathrm{Zr} / \mathrm{Y}$ ). Outro indicador é a anomalia negativa de $\mathrm{Sr}$ nos metabasaltos, similar àquelas observadas no embasamento.

Duas amostras de metabasaltos (WPR-320 e WPR-116) apresentam valores para $f_{\mathrm{Sm} / \mathrm{Nd}}$ compatíveis para materiais máficos $(-0,14$ e $-0,01$, respectivamente), enquanto a outra (WPR-217) apresenta parâmetro compatível com crosta continental de natureza félsica $(-0,39)$, o que denota que seu sistema isotópico está perturbado. Como tal, essa amostra não será considerada na discussão. Cabe também notar que, em geral, esses metabasaltos apresentam intensa saussuritização e sericitização, processos estes observados na petrografia e em nível de afloramento (vênulas de epídoto, por exemplo - Figura 5C) e que podem afetar o sistema Sm-Nd.

Apesar de os dados geoquímicos (elementos maiores, menores e traços - Menezes Leal et al., 2008) e isotópicos 
(Nd) ainda não serem conclusivos, é possível uma estimativa preliminar da geração desses metabasaltos. Essas rochas seriam resultado de dois magmas contaminados em diferentes proporções: (i) gerado a partir de mistura de manto depletado e manto enriquecido profundo (baixas razões $\mathrm{Zr} / \mathrm{Y}$ e $\mathrm{Nb} / \mathrm{Y}, \varepsilon_{\mathrm{Nd}(2,2 \mathrm{Ga})}=+2,3$ ); (ii) gerado pela mistura de OIB e manto enriquecido (altas razões $\mathrm{Zr} / \mathrm{Y}$ e $\mathrm{Nb} / \mathrm{Y}$, $f_{\mathrm{Sm} / \mathrm{Nd}}=-0,39$ e $\left.\mathrm{T}_{\mathrm{DM}}=2,6 \mathrm{Ga}\right)$, o qual teve variável contaminação de rochas crustais (e.g., Complexo Gnáissico Migmatítico Riacho de Santana).

Tentativamente, foi calculada a idade $\mathrm{T}_{\mathrm{DM}}$ da amostra WPR-320, cujo valor é de 2,6 Ga. Com base no seu parâmetro $\varepsilon_{\mathrm{Nd}(2,2 \mathrm{Ga})}=+1,14$, essa idade representaria uma idade de residência crustal (Arndt e Goldstein, 1987), combinando o componente juvenil (Paleoproterozoico) e o crustal (Arqueano) (Tabela 2). A amostra WPR-116 possui $\varepsilon_{\mathrm{Nd}(0)}$ positivo $(+2,1)$, compatível com material de natureza predominantemente mantélica. Em função do exposto, a idade isocrônica $\mathrm{Sm} / \mathrm{Nd}$ de ca. 3,2 Ga para essas rochas (ver seção anterior) não tem significado geológico.

\section{Batólito Guanambi}

Esta unidade foi datada pelos métodos $\mathrm{Pb} / \mathrm{Pb}$ (zircão por evaporação) e $\mathrm{Sm} / \mathrm{Nd}$ rocha total em riolitos (possivelmente, equivalente félsico das rochas granitoides).

A amostra WPR-208 foi analisada pelo método $\mathrm{Pb}-\mathrm{Pb}$, por meio de 20 cristais de zircão. Contudo, apenas 4 destes (cristais 8, 13, 16 e 18) forneceram sinal de $\mathrm{Pb}$ suficiente para análise isotópica. As idades aparentes ${ }^{207} \mathrm{~Pb} /{ }^{206} \mathrm{~Pb}$ variaram entre $1960 \pm 29$ e $2036 \pm 29 \mathrm{Ma}$, definindo uma idade média de $2002 \pm 32 \mathrm{Ma}$ (Tabela 4 e Figura 13). A idade mínima de cristalização dessas rochas é $2036 \pm 29 \mathrm{Ma}$, a qual é semelhante à idade de cristalização do batólito (2054 $\pm 8 \mathrm{Ma}$ ) com base em idades $\mathrm{U} / \mathrm{Pb}$ Laser Ablation (Rosa, 1999). Vale também observar que a idade ${ }^{207} \mathrm{~Pb} /{ }^{206} \mathrm{~Pb}$ de $2036 \pm 29$ Ma refletiria uma idade mínima (comparável dentro do erro com a idade $\mathrm{U} / \mathrm{Pb}$ ) para o equivalente efusivo do batólito Guanambi.

Finalmente, foram analisadas três amostras pelo método Sm-Nd de corpos subvulcânicos riolíticos associados ao batólito Guanambi. As idades $\mathrm{T}_{\mathrm{DM}}$ obtidas são semelhantes, de 2,7 a $2,6 \mathrm{Ga}\left(f_{\mathrm{Sm} / \mathrm{Nd}}=-0,55\right.$ a $\left.-0,34\right)$, ao passo que os valores de $\varepsilon_{\mathrm{Nd}(t=2,0 \mathrm{Ga})}$ ã̃o variáveis, porém negativos $(-8,0 ;-4,8$ e -4,2). O valor mais negativo é semelhante ao obtido por Rosa (1999) em outras amostras do batólito. De todo modo, a tendência negativa desse parâmetro petrogenético indica uma gênese a partir da fusão parcial de material crustal (ver Tabela 2). Esse fato é coerente com a assinatura geoquímica reportada para os corpos sieníticos e monzoníticos do batólito Guanambi, a exemplo: enriquecimento em elementos incompatíveis, como $\mathrm{Ba}, \mathrm{Sr}$ e $\mathrm{Rb}$, baixos conteúdos de $\mathrm{Nb}$, Th e $\mathrm{Pb}$ e teores elevados de $\mathrm{Cr}$ e

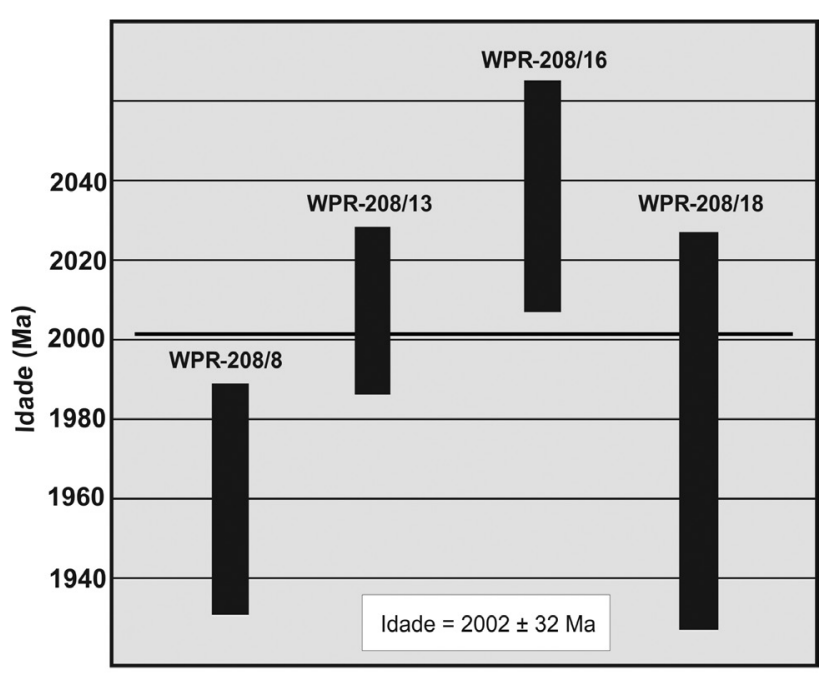

\section{Zircão}

Figura 13. Diagrama idade (Ma) média dos zircões da amostra subvulcânica félsica WPR-208 (batólito Guanambi).

Ni. O conjunto de dados geoquímicos suporta um modelo de fusão parcial de um manto metassomatizado para a origem do batólito, com participação de componentes crustais (Rosa et al., 2000; Barbosa, 2010).

\section{SÚMULA E EVOLUÇÃO CRUSTAL}

O panorama geotectônico do BGO é marcado por múltiplos eventos magmáticos e tectônicos do Paleo- ao Neoarqueano, além de dois eventos no Paleoproterozoico. A geração da crosta mais primitiva é representada pelo complexo Gnáissico Migmatítico Riacho de Santana. Rochas desse complexo indicaram idade $\mathrm{T}_{\mathrm{DM}}$ de $3,9 \mathrm{Ga}$ e $\mathrm{U} / \mathrm{Pb}$ de $3648 \pm 69$ Ma que representa a cristalização de uma de suas rochas. $O$ valor de $\varepsilon_{\mathrm{Nd}(3,6 \mathrm{Ga})}=-3,5$ confirma que a cristalização dessa rocha envolveu material muito primitivo.

Para o Complexo Santa Isabel, obteve-se uma idade $\mathrm{U} / \mathrm{Pb}$ de cristalização de $2954 \pm 100 \mathrm{Ma}$. De outra parte, o diagrama também registra uma análise com idade de $2250 \pm 2 \mathrm{Ma}$, interpretada aqui como de um evento de retrabalhamento crustal possivelmente associado temporalmente ao desenvolvimento de cinturões paleoproterozoicos no Cráton do São Francisco. As idades $\mathrm{T}_{\mathrm{DMs}}$ disponíveis para este complexo $(3,3$ a $3,1 \mathrm{Ga})$ e a variação dos parâmetros de $\varepsilon_{\mathrm{Nd}(2,9 \mathrm{Ga})}(-4,7 ;-1,4 ;-1,3 ;+0,3)$ sugerem uma gênese a partir de retrabalhamento de protólitos mesoarqueanos com curta vivência crustal. O padrão geocronológico do Complexo Santa Isabel, comparado com o do Complexo Gnáissico Migmatítico Riacho de Santana, implica uma evolução crustal particular para cada uma das unidades basais da área estudada. Por outro lado, a 
existência de rochas metagranitoides no Complexo Santa Isabel, com idade mínima $\mathrm{Pb} / \mathrm{Pb}$ (método por evaporação) de $1966 \pm 38 \mathrm{Ma}$, aponta ainda a existência de um evento superposto posterior ao batólito Guanambi.

O greenstone belt Riacho de Santana, datado pelo método U-Pb em zircão, forneceu idade de $2218 \pm 18 \mathrm{Ma}$, interpretada como de cristalização (Rodrigues et al., 2012). Infelizmente, não há como avaliar criticamente essa interpretação, uma vez que os dados analíticos não estão publicados. Das três análises Sm-Nd realizadas, apenas uma apresenta evolução isotópica de $\mathrm{Nd}$ compatível com material derivado predominantemente do manto. Por outro lado, outra amostra tem idade $\mathrm{T}_{\mathrm{DM}}$ de $2,6 \mathrm{Ga}$, que denota a presença de contaminante crustal. Essa hipótese é corroborada pela interpretação geoquímica desses metabasaltos por Menezes Leal et al. (2008).

O batólito Guanambi, com idade U/Pb de $2054 \pm 8 \mathrm{Ma}$, representa um estágio de grande expressão magmática da região. Trata-se de rochas monzoníticas e sieníticas com característica geoquímica consistente com ambiente sina pós-colisional (Rosa, 1999). A assinatura isotópica das rochas do batólito é caracterizada por valores negativos de $\varepsilon_{\mathrm{Nd}(2,0 \mathrm{Ga})}(-7,4$ a $-10,6)$ e de ${ }^{87} \mathrm{Sr}^{8}{ }^{86} \mathrm{Sr}_{\mathrm{i}}(0,704$ a 0,707$)$ que são compatíveis com geração a partir de um manto metassomatizado. Contudo, em nossa opinião, face aos valores negativos de $\varepsilon_{\mathrm{Nd}(2,0 \mathrm{Ga})}$, esse magma teria também contaminação crustal, o que é corroborado pelas idades $\mathrm{T}_{\mathrm{DM}}$ em rochas subvulcânicas $(2,8-2,6 \mathrm{Ga})$ e ainda pela presença de xenólitos do embasamento (ver Figura 5D).

Em termos geotectônicos, a idade de $2218 \pm 18$ Ma obtida para o greenstone belt, a idade de $2250 \pm 2$ Ma obtida para o evento de retrabalhamento no Complexo Santa Isabel e ainda a geração de rochas granitoides associadas ao batólito Guanambi implicam a existência de um evento tectonomagmático riaciano no $\mathrm{BGO}$, já anteriormente aventado por outros autores com denominações diversas (e.g., cinturões Urandi-Paratinga, Guanambi-Correntina Mascarenhas, 1979; Brito Neves et al., 1980; Barbosa e Dominguez, 1996; Rosa, 1999). Tentativamente, propomos que o magma progenitor do greenstone belt Riacho de Santana apresenta assinatura de Nd $(+2,8 ;+1,1)$ de manto metassomatizado em ambiente de arco.

O diagrama ${ }^{87} \mathrm{Sr} /{ }^{86} \mathrm{Sr}$ versus tempo (Figura 14) ilustra a evolução de três unidades do $\mathrm{BGO}$, comparativamente à do manto superior, com base na integração de dados preexistentes e na avaliação crítica dos dados $\mathrm{Rb} / \mathrm{Sr}$ de cada uma dessas unidades (Anexo 1). O Complexo Gnáissico Migmatítico Riacho de Santana (idade Rb/Sr de 3,2 Ga), representado pela evolução cinza-escura, possui razões atuais ${ }^{87} \mathrm{Sr} r{ }^{86} \mathrm{Sr}$ entre 0,707 a 0,804 . Com base no diagrama, pode-se sugerir que o Complexo Santa Isabel $(2,7 \mathrm{Ga})$ possui componentes crustais derivados do Complexo Gnáissico Migmatítico. Para as amostras do batólito
Guanambi $(2,0 \mathrm{Ga})$, foram representadas as variações dos valores de ${ }^{87} \mathrm{Sr} /{ }^{86} \mathrm{Sr}$ nas isócronas publicadas, por meio de linhas tracejadas e dos valores da razão inicial das isócronas que variam de 0,705 a 0,712 . Isso indica que tais rochas derivaram de protólitos diversos, possivelmente materiais do Complexo Santa Isabel, do Complexo Gnáissico Migmatítico e mesmo do greenstone belt Riacho de Santana, conforme sugere a composição de xenólitos.

No intuito de detalhar o aspecto petrogenético regional, foi feita uma integração dos dados isotópicos de $\mathrm{Nd}$ dos complexos Gnáissico Migmatítico Riacho de Santana e Santa Isabel e do batólito Guanambi, representados em um diagrama de evolução isotópica de $\mathrm{Nd}$ versus tempo (Figura 15). As linhas de evolução das duas unidades basais e das rochas subvulcânicas félsicas do batólito Guanambi foram obtidas deste trabalho, ao passo que a faixa cinza-clara representa os dados da literatura do batólito Guanambi (Rosa, 1999). As amostras do substrato metamórfico apresentam evolução de $\mathrm{Nd}$ típica para crosta continental antiga. As amostras do batólito Guanambi apresentam uma evolução própria, com base em dados compilados da literatura (características isotópicas $\varepsilon_{\mathrm{Nd}(2,0 \text { Ga) }}=-7,4$ a $-10,6$ e ${ }^{87} \mathrm{Sr} r{ }^{86} \mathrm{Sr}_{\mathrm{i}}$ entre 0,704 e 0,707 - Rosa, 1999). O padrão reflete novamente uma derivação a partir da mistura de componente mantélico e crustal há $2,0 \mathrm{Ga}\left(\operatorname{com} \varepsilon_{\mathrm{Nd}(2,0 \mathrm{Ga})}\right.$ entre -7 e -8). Essa assinatura crustal é compatível com materiais associados ao Complexo Santa Isabel, que apresenta $\mathrm{T}_{\mathrm{DM}}$ entre 3,3 e 3,1 Ga. De fato, as idades $\mathrm{T}_{\mathrm{DM}}$ das rochas do batólito são neoarqueanas $(2,8$ e 2,7 Ga). Para as rochas subvulcânicas, que são interpretadas como coevas às rochas plutônicas do batólito, os respectivos $\varepsilon_{\mathrm{Nd}(2,0 \mathrm{Ga})}$ são menos negativos (uma delas com -4,2), comparativamente às análises da literatura $\left(\varepsilon_{\mathrm{Nd}(2,0 \mathrm{Ga})}=-7 \mathrm{a}-10\right)$. Isso sugere diferentes proporções do componente crustal na gênese dessas rochas. As características geoquímicas indicam que esse batólito e as rochas subvulcânicas coevas são produtos de cristalização fracionada de um magma lamprofírico gerado pela fusão de um manto paleoproterozoico enriquecido (Rosa, 1999).

Em suma, a interpretação integrada das idades $\mathrm{U}-\mathrm{Pb}, \mathrm{Rb}-\mathrm{Sr}, \mathrm{Pb}-\mathrm{Pb}$ e K-Ar e dos dados geoquímicos nas unidades litoestratigráficas do BGO permitiu novas inferências acerca da evolução crustal desse segmento crustal. A Figura 16 esboça a evolução genética do BGO, ilustrando a acreção magmática paleoarqueana a partir de fontes juvenis do Complexo Gnáissico Migmatítico Riacho de Santana. Esse evento é seguido de cristalização e posterior remobilização isotópica desse complexo e acreção do Complexo Santa Isabel durante o Mesoarqueano. Já no Neoarqueano, ocorre uma remobilização isotópica (Complexo Santa Isabel), caracterizada como migmatização regional. Posteriormente, no Paleoproterozoico, foi identificado 


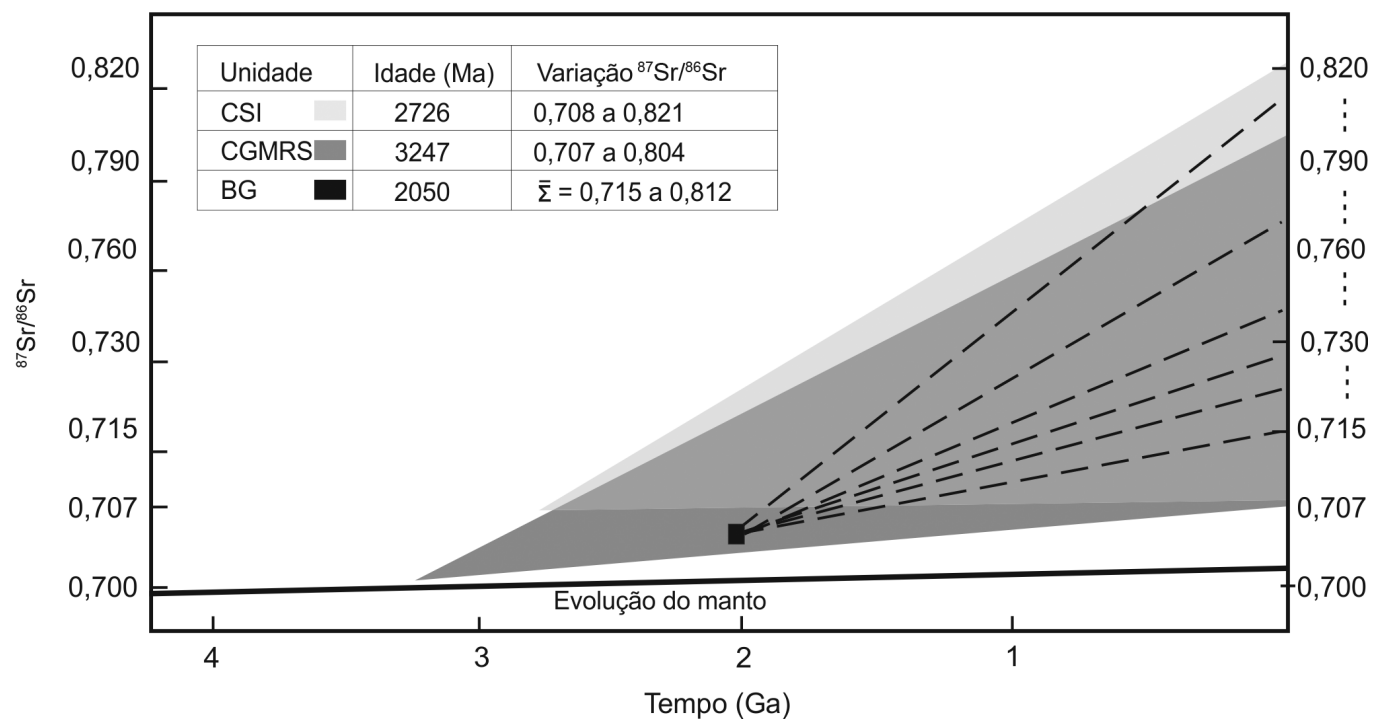

CSI: Complexo Santa Isabel; CGMRS: Complexo Gnáissico Migmatítico Riacho de Santana; BG: Batólito Guanambi.

Figura 14. Diagrama ${ }^{87} \mathrm{Sr} /{ }^{86} \mathrm{Sr}$ (atual) versus tempo para as rochas do Complexo Santa Isabel, Complexo Gnáissico Migmatítico Riacho de Santana e Batólito Guanambi. Os valores $\left({ }^{87} \mathrm{Sr} /{ }^{86} \mathrm{Sr}\right)$ estão apresentados no Anexo 1.

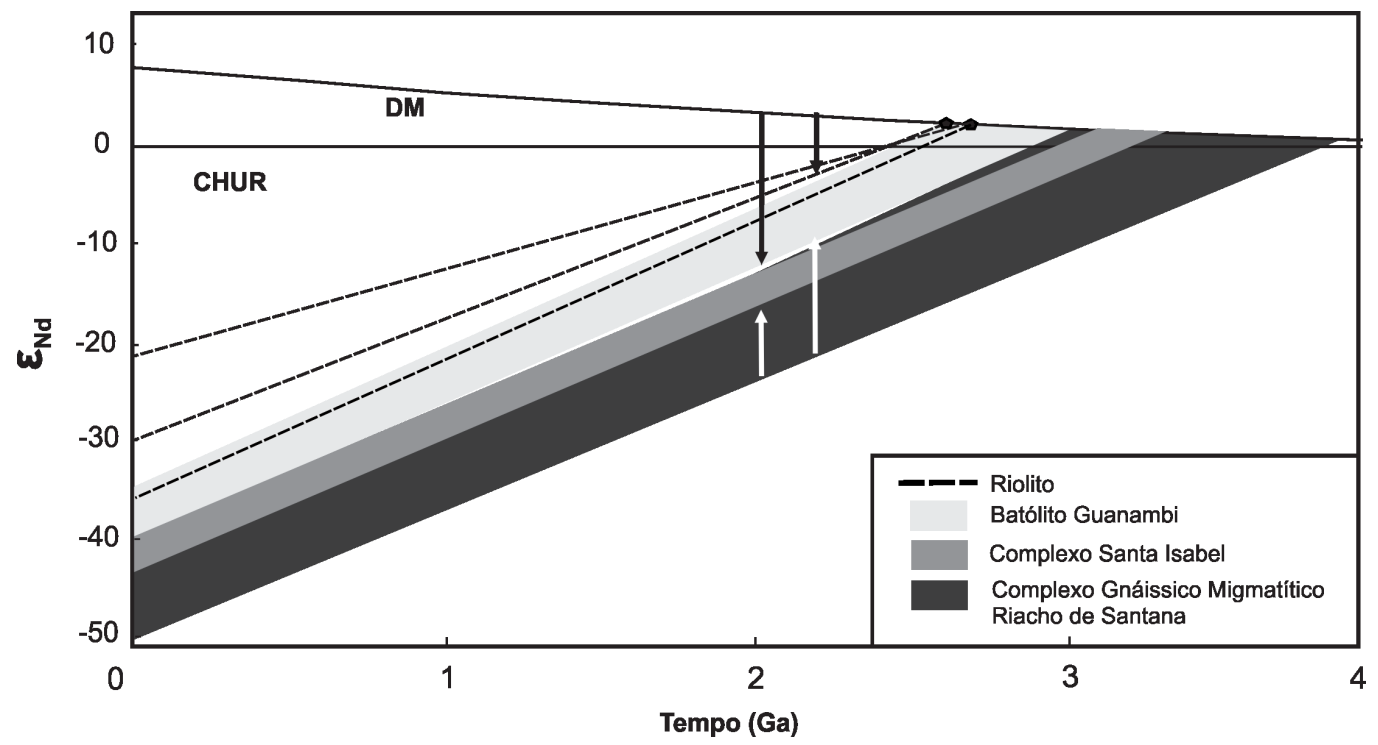

Figura 15. Diagrama $\varepsilon_{(\mathrm{Nd})}$ versus tempo mostrando a evolução das rochas do Bloco Gavião Oeste (as setas significam mistura de fontes mantélica e crustal).

geocronologicamente um retrabalhamento do Complexo Santa Isabel, formaram-se o greenstone belt Riacho de Santana e o batólito Guanambi. A petrogênese deste último envolveu componente juvenil com proporções variáveis de material crustal.

O quadro evolutivo (Figura 16) estabelece as idades de cristalização, conforme sumarizado a seguir: (i) $3,6 \mathrm{Ga}-$ formação do Complexo Gnáissico Migmatítico Riacho de
Santana; (ii) $2,9 \mathrm{Ga}$ - formação das rochas do Complexo Santa Isabel; (iii) 2,2 Ga - cristalização do greenstone belt Riacho de Santana e metamorfismo granulítico no Complexo Santa Isabel; (iv) 2,0 Ga - cristalização do batólito Guanambi (Figura 16). No Proterozoico, o BGO foi ainda reativado tectonicamente, há 1,7 - 1,6 Ga e 660 - 520 Ma.

Os dados geocronológicos na área estudada (Bloco Gavião Oeste) ilustram uma evolução diacrônica 
comparativamente às outras regiões desse bloco arqueano. Apesar de Barbosa et al. (2012) considerarem a nomenclatura da região estudada como Bloco Gavião Oeste, os dados aqui apresentados demonstram que esse segmento crustal obteve uma dinâmica paleoproterozoica individualizada do Bloco Gavião Sul e central (e.g., granitos sin- e pós-tectônicos paleoproterozoicos). As porções sul e central do Bloco Gavião possuem rochas de composição TTG, com idade variando entre $3420 \pm$ 9 e $2559 \pm 110 \mathrm{Ma}$ (Barbosa et al., 2012). As diversas sequências do tipo greenstone belt ainda não apresentam idades precisas, mas são interpretadas como de idade arqueana (Cunha et al., 2012). No contexto evolutivo do Bloco Gavião Sul, pode ser exemplificado o greenstone belt Umburanas, datado por $\mathrm{Pb}-\mathrm{Pb}$ evaporação em zircão em meta-andesito da unidade intermediária, que revelou idade de cristalização magmática de $2744 \pm$
15 Ma (Bastos Leal et al., 2003). Ainda na porção sul, o Complexo Gnáissico Migmatítico (embasamento do greenstone belt Umburanas) apresentou idades $\mathrm{Rb}-\mathrm{Sr}$ de 2,7 e 3,1 Ga. De outra parte, rochas granitoides intrusivas de porções variadas do Cráton são relativamente cronocorrelatas ao batólito Guanambi, com idades entre 2061 \pm 9 e $1929 \pm 16 \mathrm{Ma}$ (Barbosa et al., 2012). Em termos de correlação regional, a área de trabalho guarda certa semelhança com outros blocos primitivos situados no extremo leste do Cráton do São Francisco. A título de exemplo, tem-se o Bloco Serrinha, que é composto por rochas de afinidade TTG, granulitos migmatizados e metamorfisados na fácies anfibolito, além de sequências vulcanossedimentares paleoproterozoicas (e.g., Itapicuru, Rio Capim) intrudidas por rochas coevas (e.g., Alves da Silva, 1994; Rios et al., 2009; Oliveira et al., 2010). Migmatitos e granitoides representantes do embasamento regional

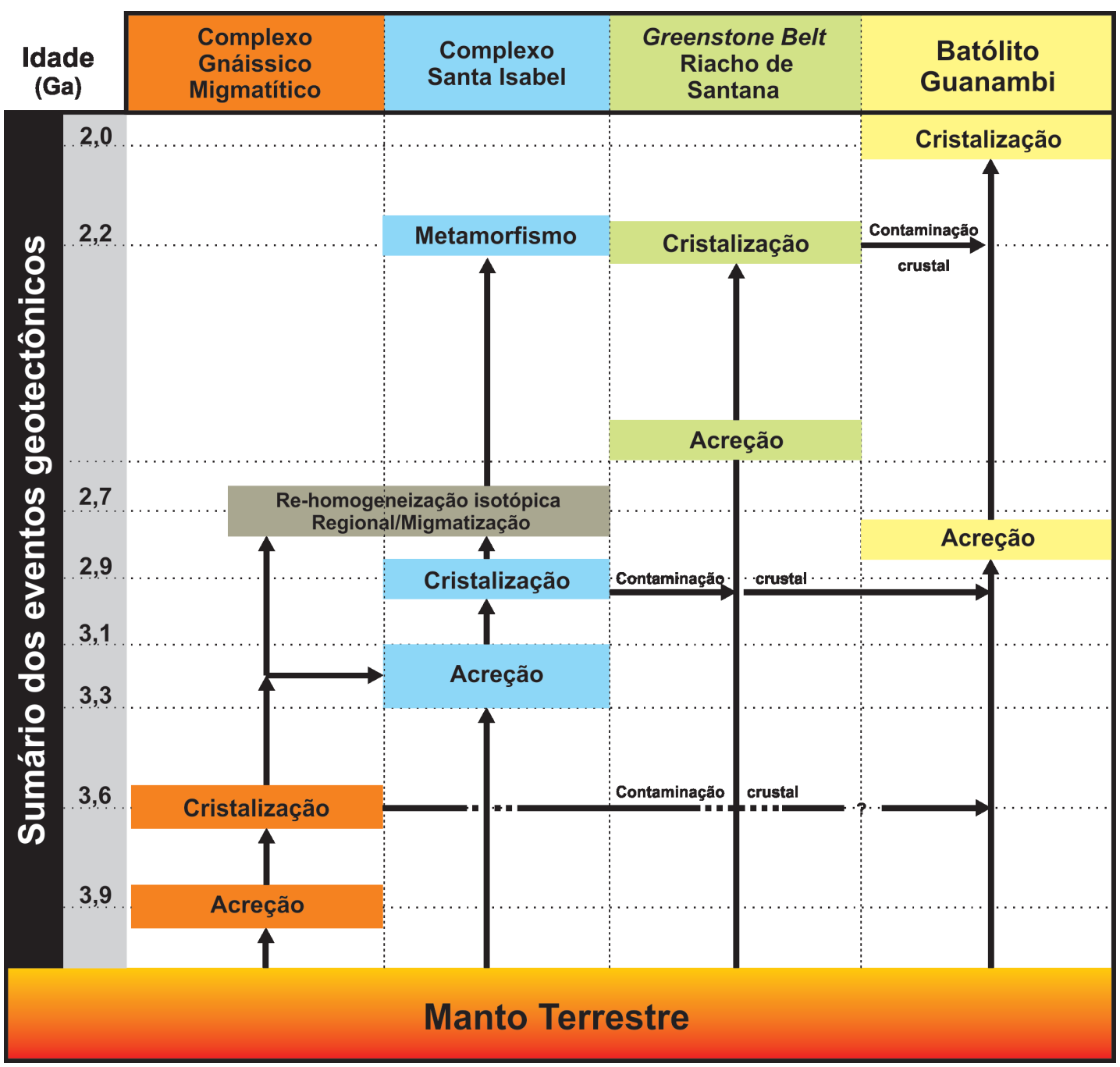

Figura 16. Diagrama mostrando a evolução genética do Bloco Gavião Oeste. 
apresentam idades de $3102 \pm 5,3085 \pm 6$ e $2989 \pm 11 \mathrm{Ma}$ (Oliveira et al., 2010; Rios et al., 2009). Já o magmatismo do greenstone belt Itapicuru apresenta idades $\mathrm{U} / \mathrm{Pb}$ entre $2081 \pm 8$ e $2142 \pm 6 \mathrm{Ma}\left(\mathrm{T}_{\mathrm{DM}}\right.$ de $2,2 \mathrm{Ga}$ ), enquanto o greenstone belt Rio Capim tem idade de $2148 \pm 9 \mathrm{Ma}$ (Oliveira et al., 2010). Contudo, no contexto evolutivo do Paleoproterozoico, a evolução dessas sequências é mais jovem do que aquela interpretada para o greenstone belt Riacho de Santana (2218 $\pm 18 \mathrm{Ma}$ ) situado no BGO. De todo modo, consideramos que todos esses registros estão tectonicamente vinculados ao desenvolvimento de cinturões paleoproterozoicos (e.g., Cinturão ItabunaSalvador-Curaçá e Cinturão Mineiro) das porções norte e sul, respectivamente, do Cráton do São Francisco.

\section{AGRADECIMENTOS}

Os autores agradecem aos técnicos dos laboratórios envolvidos na presente pesquisa (CPGeo - USP, Laboratório de Geoquímica Isotópica - Universidade do Texas e Pará-Iso - UFPA), a M. A. S. Basei pela discussão dos resultados U/Pb Laser Ablation e a M. L. S. Rosa, J. B. Rodrigues, J. Prazeres Santos e J. S. Souza pela liberação de dados referentes à área de estudo. N. S. Barbosa agradece à Coordenação de Aperfeiçoamento de Pessoal de Nível Superior (CAPES) pela bolsa de Mestrado. W. Teixeira agradece ao Conselho Nacional de Desenvolvimento Científico e Tecnológico (CNPq) pelo contínuo apoio aos estudos no Cráton do São Francisco.

\section{REFERÊNCIAS}

Alkmim, F. F. (2004). O que faz um Cráton um Cráton? O Cráton São Francisco e as revelações Almeidianas ao delimitá-lo. In: V. Mantesso-Neto, A. Artorelli, C. D. R. Carneiro, B. B. Brito Neves (Eds.), Geologia do continente Sul-americano: evolução da obra de Fernando Flávio Marques de Almeida (v. 1, 17-35). São Paulo: Beca.

Alkmim, F. F., Brito Neves, B. B., Alves, J. A. C. (1993). Arcabouço tectônico do Cráton do São Francisco: Uma revisão. In: J. M. L. Dominguez, A. Misi (Eds.), O Cráton do São Francisco (v. 1, 45-62). Salvador: SBG.

Alkmim, F. F., Martins-Neto, M. A. (2012). Proterozoic first-order sedimentary sequences of the São Francisco craton, eastern Brazil. Marine and Petroleum Geology, 33(1), 127-139.

Almeida, F. F. M. (1977). O Cráton do São Francisco. Revista Brasileira de Geociências, 7(4), 349-364.
Alves da Silva, F. C. (1994). Étude structurale du Greenstone Belt Paleoproterozoique du Rio Itapicuru (Bahia, Brésil). 311p. Tese (Doutorado). Orléans: Université d'Orléans.

Arndt, N. T., Goldstein, S. L. (1987). Use and abuse of crust-formation ages. Geology, 15(10), 893-895.

Barbosa, J. S. F., Cruz, S. P., Souza, J. S. (2012). Terrenos Metamórficos do Embasamento. In: J. S. F. Barbosa, J. F. Mascarenhas, L. C. Corrêa-Gomes, J. M. L. Dominguez, J. S. de Souza (Eds.), Geologia da Bahia: Pesquisa e atualização (v. 1, 101-199). Salvador: CPBM; UFBA.

Barbosa, J. S. F, Dominguez, J. M. L. (1996). Texto Explicativo para o Mapa Geológico do estado da Bahia. Escala 1:1.000.000. Salvador: Secretaria da Indústria Comércio e Mineração do Estado da Bahia/SGM/PPPG/ FAPEX/CPGG.

Barbosa, J. S. F., Peucat, J. J., Martin, H., Silva, F. C. A., Corrêia-Gomes, L. C., Sabaté, P., Marinho, M. M., Fanning, C. M., Moraes, A. M. V. (2008). Petrogenesis of the late-orogenic Bravo granite and surrounding high-grade country rocks in the Paleoproterozoic orogen of ItabunaSalvador-Curaçá Block, Bahia, Brazil. Precambrian Research, 167(3), 35-52.

Barbosa, J. S., Sabaté, P. (2004). Archean and Paleoproterozoic crust of the São Francisco cráton, Bahia, Brazil: geodynamic feactures. Precambrian Research, 133(3), 1-27.

Barbosa, J. S. F., Sabaté, P., Marinho, M. M. (2003). O Cráton do São Francisco na Bahia: uma síntese. Revista Brasileira de Geociências, 33(1), 3-6.

Barbosa, N. S. (2010). Geocronologia dos terrenos granito-greenstone da região de Riacho de Santana, Bahia. Dissertação (Mestrado). Salvador: Instituto de Geociências - UFBA.

Bastos Leal, L. R., Cunha, J. C., Cordani, U. G., Teixeira, W., Nutman, A. P., Menezes Leal, A. B., Macambira, M. J. B. (2003). SHRIMP U-Pb, ${ }^{207} \mathrm{~Pb} / 206 \mathrm{~Pb}$ zircon dating, and $\mathrm{Nd}$ isotopic signature of the Umburanas greenstone belt, northern São Francisco craton, Brazil. Jounal of South American Earth Science, 15(7), 775-785.

Bennett, V. C., De Paolo, D. J. (1987). Proterozoic crustal history of the western United States as determined by neodymiom isotopic mapping. Geological Society of America Bulletin, 99(5), 674-685. 
Brito Neves, B. B., Cordani, U. G., Torquato, J. R. F. (1980). Evolução Geocronológica do Pré-Cambriano do Estado da Bahia. In: H. A. V. Inda, F. B. Duarte (Eds.), Geologia e Recursos Minerais do Estado da Bahia (v. 3, 1-101, Textos Básicos). Bahia: SME/COM.

Companhia de Pesquisa de Recursos Minerais - CPRM (2004). Carta Geológica do Brasil ao Milionésimo: sistema de informações geográficas - SIG [Mapa geológico do Brasil, Escala: 1:1.000.000. Sistema de informações geográficas - GIS], v. 41. Brasília: CPRM. CD-ROM. Programa Geologia do Brasil.

Conceição, H., Rios, D. C., Rosa M. L. S., Davis, D. W., Dickin, A., MCreath, I., Marinho, M. M., Macambira, M. J. B. (2002). Zircon Geochronology and Petrology of Alkaline-Potassic Syenites, Southwestern Serrinha Nucleus, East São Francisco Craton, Brazil. International Geology Review, 44, 117-136.

Cordani, U. G. (1973). Evolução geológica précambriana da faixa costeira do Brasil, entre Salvador e Vitória. Tese (Livre Docência). São Paulo: Instituto de Geociências - USP.

Cordani, U. G., Iyer, S. S., Taylor, P. N., Kawashita, K., Sato, K., MCreath, I. (1992). Pb/Pb, Rb/Sr, and K-Ar sistematic of the Lagoa Real uranium province (southcentral Bahia, Brazil) and the Espinhaço Cycle (ca. 1.5$1.0 \mathrm{Ga})$. Journal of South American Earth Sciences, 5(1), 33-36.

Cordani, U. G., Sato, K., Marinho, M. M. (1985). The geologic evolution of the ancient granite-greenstone terrane of central-southern Bahia, Brazil. Precambrian Research, 27(7), 187-213.

Cruz, S. C. P. (2004). Tectônica do Embasamento na Porção Sul do Corredor do Paramirim-MG/BA e sua relação com o orógeno Araçuai-Oeste Congo. Tese (Doutorado). Ouro Preto: Departamento de Geologia - UFOP.

Cruz, S. C. P., Alkmim, F. F. (2007). A história de inversão do Aulacógeno do Paramirim contada pela sinclinal de Ituaçu, extremo sul da Chapada Diamantina (BA). Revista Brasileira de Geociências, 37(4), 92-110.

Cunha, J. C., Barbosa, J. S. F., Mascarenhas, J. F. (2012). Greenstone Belts e sequências similares. In: J. S. F. Barbosa, J. F. Mascarenhas, L. C. Corrêa-Gomes, J. M.
L. Dominguez, J. S. de Souza (Eds.), Geologia da Bahia: Pesquisa e atualização (1a ed., v. 1, 203-325). Salvador: CPBM; UFBA.

Danderfer, A., De Waele, B., Pedreira, A., Nalini, H. A. (2009). New geochronological constraints on the geological evolution of Espinhaço basin within the São Francisco craton - Brazil. Precambrian Research, 170(1-2), 116-128.

Dantas, E. L., Neves, B. B. B., Fuck, R. A. (2010). Looking for the oldest rocks of South America: Paleoarchean orthogneiss from the Sobradinho block, northernmost foreland of the São Francisco Craton, Petrolina, Pernambuco, Brazil. VII South America Symposium on Isotope Geology. Brasília. CD-ROM.

De Paolo, D. J. (1988). Neodymium Isotope Geochemistry: An Introduction (1a ed.). New York: Springer-Verlag.

De Paolo, D. J., Linn, A. M., Schubbert, G. (1991). The continental age distribution: methods of determining mantle separation ages from $\mathrm{Sm}-\mathrm{Nd}$ isotopic data and application to the southwestern United States. Journal of Geophysical Research, 96(2), 2071-2088.

Fernandes, P. C. E. A., Montes, M. L., Braz, E. R. C., Montes, A. S. L., Silva, L. L., Oliveira, F. L. L., Ghignone, J. I., Siga Júnior, O., Castro, H. E. F. (1982). Geologia. In: Projeto Radambrasil (v. 29, 25-204). Folha SD. 23 Brasília: MME/SG; Rio de Janeiro: Publicação do projeto Radambrasil.

Fróes, R. J. B, Silveira, W. P. (1996). Séries magmáticas do greenstone belt de Riacho de Santana - Bahia. XXXIX Congresso Brasileiro de Geologia, v. 2, 100-103. Salvador: SBG.

Gaudette, H. E., Lafon, J. M., Macambira, M. J. B., Moura, C. A. V., Scheller, T. (1998). Comparison of single filament $\mathrm{Pb}$ evaporation/ionization zircon ages with conventional U-Pb results: examples from the Precambrian of Brazil. Journal of South American Earth Sciences, 11(4), 351-363.

Jardim de Sá, E. F, McReath, I., Brito Neves, B. B., Bartels, R. L. (1976). Novos dados geocronológicos sobre o Cráton do São Francisco no Estado da Bahia. XXIX Congresso Brasileiro de Geologia, v. 5, 186-204. Ouro Preto: SBG. 
Ludwig, K. G. (2000). Isoplot 3.0: a geochronological toolkit for Microsoft Excel (2a ed, v. 4). Berkeley: Berkeley Geochronology Center Special Publication.

Marinho, M. M. (1991). La séquence volcanosedimentaire de Contendas-Mirante et la bordure occidentale du Bloc Jequié (Cráton du São FranciscoBrésil): un exemple de transition ArchéeanProtérozoique. Tese (Doutorado). Clermont Ferrand: Université Blaise Pascal Clermont Ferrand II.

Martin, H., Sabaté, P., Peucat, J. J., Cunha, J. C. (1991). Un segment de croûte continentale d'âge archéen ancient (3.4 milliards d'années): le massif de Sete Voltas (Bahia, Brésil). Comptes Rendus de l'Academie des Sciences, 313, 531-538.

Martin, H., Sabaté, P., Peucat, J. J., Cunha, J. C. (1997). Crustal evolution in early Archaean of South America: example of the Sete Voltas Massif, Bahia state, Brazil. Precambrian Research, 82(1-2), 35-62.

Mascarenhas, J. F. (1979). Evolução Geotectônica do Precambriano do Estado da Bahia. In: H. A. V. Inda (Ed.), Geologia e Recursos Minerais do Estado da Bahia (v. 2, 57-165, Textos Básicos). Salvador: SME/CPM.

Mascarenhas, J. F., Garcia, T. W. (1989). Mapa Geocronológico do Estado da Bahia: Texto Explicativo. Salvador: Superintendência de Geologia e Recursos Minerais, Secretaria de Minas e Energia.

Mascarenhas, J. F., Pedreira, A. J., Misi, A., Motta, A. C., Silva-Sá, J. H. (1985). Província São Francisco. In: F. F. M. Almeida, Y. Hasui (Eds.), O Pré-Cambriano do Brasil (v. 1, 46-122). São Paulo: Edgar Blücher.

Menezes Leal, A. B., Paul, D., Silveira, W. P., Bastos Leal, L. R., Cruz, S. C. P., Prazeres Santos, J. (2008). Geoquímica das rochas meta-vulcânicas máficas do greenstone belt de Riacho de Santana, Bahia, Brasil. Revista Brasileira de Geociências, 38(3), 476-487.

Michard, A., Gurriet, P., Soundant, M., Albarede, F. (1985). Nd isotopes in French Phanerozoic shales: external vs. internal aspects of crustal evolution. Geochimica et Cosmochimica Acta, 49(2), 601-610.

Moutinho da Costa, L. A., Silva, W. G. (1980). Projeto Santo Onofre: mapeamento geológico. Relatório Final. TRISERVICE. Convênio CPRM/DNPM. 21 vols.
Oliveira, E. P., McNaughton, N. J., Armstrong, R. (2010). Mesoarchaean to Palaeoproterozoic growth of the northern segment of the Itabuna-Salvador Curaçá-orogen, São Francisco craton, Brazil. Geological Society (London, Special Publications), 338, 263-286.

Oliveira, E. P., Souza, Z. S., McNaughton, N. J., Lafon, J. M., Costa, F. G., Figueiredo, A. M. (2011). The Rio Capim volcanic-plutonic-sedimentary belt, São Francisco Craton, Brazil: Geological, geochemical and isotopic evidence for oceanic arc accretion during Palaeoproterozoic continental collision. Gondwana Research, 19(3), 735-750.

Paim, M. M., Rosa, M. L. S., Conceição, H., Barreto Santos, E., Bastos Leal, L. R. (1999). Aspectos geoquímicos dos lamprofiros (minettes) associados ao maciço sienítico de Cara Suja - Sudoeste da Bahia. VII Congresso Brasileiro de Geoquímica, v. 5, 566-568. Porto Seguro: SBG.

Portela, A. C. P., Marchetto, L. A., Santos, E. L., Meneguesso, G., Stein, J. H., Moutinho da Costa, L. A. (1976). Projeto Leste de Tocantins-Oeste do Rio São Francisco (Letos). Relatório Final, MME-DNPM, Convênio DNPM-CPRM, Fase V, Texto, 557p.

Prazeres Santos, J. (2010). Rochas Meta-vulcânicas Máficas da Unidade Intermediária do greenstone belt de Riacho de Santana, Estado da Bahia: Estudo petrográfico e geoquímico. Dissertação (Mestrado). Salvador: Instituto de Geociências - UFBA.

Rios, D. C. (2002). Granitogenese no Núcleo Serrinha, Bahia, Brasil: Geocronologia e litogeoquimica. Tese (Doutorado). Salvador: Instituto de Geociências - UFBA.

Rios, D. C., Davis, D. W., Conceição, H., Rosa, M. L. S., Davis, W. J., Dickin, A. P. (2009). Geologic evolution of the Serrinha nucleus granite-greenstone terrane (NE Bahia, Brazil) constrained by U-Pb single zircon geochronology. Precambrian Research, 170(3-4), 175-201.

Rios, D. C., Davis, D. W., Conceição, H., Rosa, M. L. S., Davis, W. J., Dickin, A. P., Marinho, M. M., Stern, R. (2008). 3.65-2.10 Ga history of crust formation from zircon geochronology and isotope geochemistry of the Quijingue and Euclides plutons, Serrinha nucleus, Brazil. Precambrian Research, 167(1-2), 53-70.

Rodrigues, J. B., Guimarães, J. T., Borges, V. P., Carvalho, C. B., Nogueira, A. C. (2012). Ryacian zircon age of metabasaltic rocks from Riacho de Santana Greenstone 
Belt, Bahia (Brazil). VIII South American Symposium on Isotope Geology. Medellin. CD-ROM.

Rosa, M. L. S. (1999). Geologia, Geocronologia, Mineralogia, Litogeoquímica e Petrologia do Batólito Monzo-Sienítico Guanambi-Urandi (SW-Bahia). Tese (Doutorado). Salvador: Instituto de Geociências - UFBA.

Rosa, M. L. S., Conceição, H., Oberli, F, Meier, M., Martin, H., Macambira, M. J. B., Santos, E. B., Paim, M. M., Leahy, G. A. S., Leal, L. R. B. (2000). Geochronology $(\mathrm{U}-\mathrm{Pb} / \mathrm{Pb}-\mathrm{Pb})$ and isotopic signature $(\mathrm{Rb}-\mathrm{Sr} / \mathrm{Sm}-\mathrm{Nd})$ of the Paleoproterozoic Guanambi batolith, southwestern Bahia State (NE Brazil). Revista Brasileira de Geociências, 30(1), 62-65.

Rosa, M. L. S., Conceição, H., Paim, M. M., Santos, E. B., Alves da Silva, F. C., Leahy, G. A. S., Bastos Leal, L. R. (1996). Magmatismo potássico/ultrapotássico pós a tardi-orogênico (associado a subducção) no oeste da Bahia: Batólito Monzo-Sienítico de Guanambi-Urandi e os Sienitos de Correntina. Geochimica Brasiliensis, 10(1), 27-42.

Sato, K., Tassinari, C. C. G., Kawashita, K., Petronilho, L. (1995). O método geocronológico Sm-Nd no IG/ USP e suas aplicações. Anais da Academia Brasileira de Ciências, 67(3), 313-336.

Schobbenhaus, C. (1996). As tafrogêneses superpostas Espinhaço e Santo Onofre, Estado da Bahia: Revisão e novas propostas. Revista Brasileira de Geociências, 26(4), 265-276.

Silva, M. G. (1996). Sequências Metassedimentares, Vulcanossedimentares e Greenstone Belts do Arqueano e Proterozoico Inferior. In: J. S. F. Barbosa, J. M. L. Dominguez (Eds.), Geologia da Bahia: Texto Explicativo para o Mapa Geológico ao Milionésimo (v. 1, 85-102, Special Publication). Salvador: SICM/SGM.
Silveira, W. P. (1994). A geologia da seqüência vulcanossedimentar de Riacho de Santana. XXXVIII Congresso Brasileiro de Geologia, v. 2, 91-93. Camboriú: SBG.

Silveira, W. P., Garrido, I. A. A. (2000). Geologia, pesquisa mineral e potencialidade econômica do greenstone belt Riacho de Santana (v. 14, Série Arquivos Abertos). Salvador: CBPM.

Stacey, J. S., Kramers, J. D. (1975). Approximation of terrestrial lead isotope evolution by a two-stage model. Earth and Planetary Science Letters, 26(2), 207-221.

Távora, F. J., Cordani, U. G., Kawashita, K. (1967). Determinações de idade Potássio - Argônio em rochas da Região Central de Bahia. XXI Congresso Brasileiro de Geologia, 234-244, Curitiba: SBG.

Teixeira, W., Carneiro, M. A., Noce, C. M., Machado, N., Sato, K., Taylor, P. N. (1996). Pb, Sr and Nd isotopic constraints on the Archean evolution of gneissic-granitoid complexes in the southern São Francisco Craton, Brazil. Precambrian Research, 78(1-3), 151-164.

Teixeira, W., Marques, L. S., Petroni, C. (2010). Origem e evolução da crosta arqueana do Cráton do São Francisco: uma síntese. XXXXV Congresso Brasileiro de Geologia. Belém: SBG. CD-ROM.

Teixeira, W., Sabaté, P., Barbosa, J., Noce, C. M., Carneiro, M. A. (2000). Archean and paleoproterozoic evolution of the São Francisco Craton, Brazil. In: U. G. Cordani., E. J. Milani, A. Thomaz Filho, D. A. Campos (Eds.), Tectonic evolution of South America (1a ed., v. 1, 101-137, Publicação Especial). Rio de Janeiro: SBG.

Turpin, L., Maruejol, P., Cuney, M. (1988). U-Pb, Rb-Sr and Sm-Nd chronology of granitic basement, hidrothermal albitites and uranium mineralization (Lagoa Real, South-Bahia, Brazil). Contributions to Mineralogy and Petrology, 98(2), 139-147. 
Anexo 1. Dados isotópicos Rb-Sr e K-Ardo Complexo Santa Isabel.

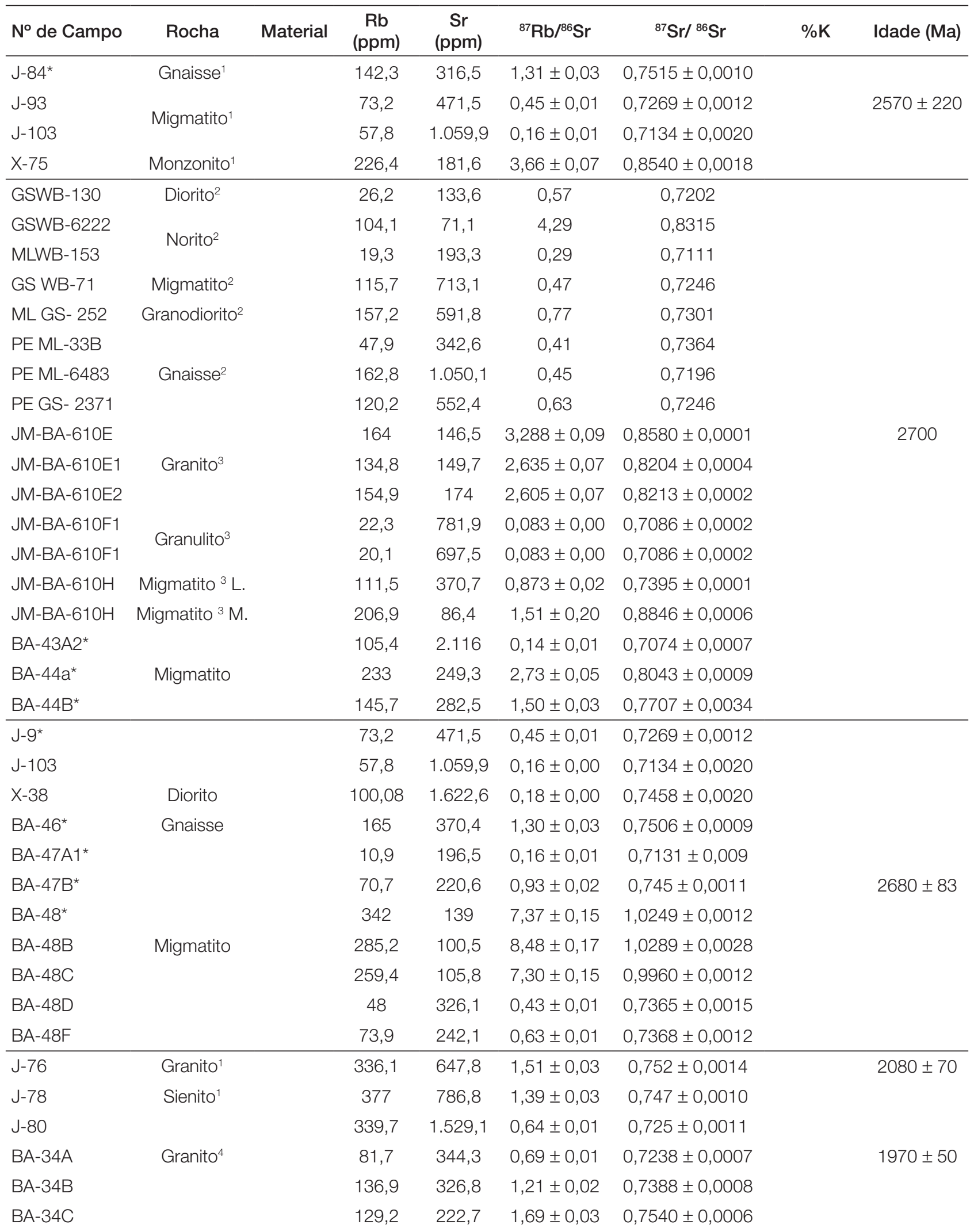

Continua... 
Anexo 1. Continuação.

\begin{tabular}{|c|c|c|c|c|c|c|c|c|}
\hline$N^{\circ}$ de Campo & Rocha & Material & $\begin{array}{c}\mathrm{Rb} \\
(\mathrm{ppm})\end{array}$ & $\begin{array}{c}\mathrm{Sr} \\
(\mathrm{ppm})\end{array}$ & ${ }^{87} \mathrm{Rb} /{ }^{86} \mathrm{Sr}$ & ${ }^{87} \mathrm{Sr} /{ }^{86} \mathrm{Sr}$ & $\% \mathrm{~K}$ & Idade (Ma) \\
\hline BA-35B & & & 253 & 89,3 & $8,39 \pm 0,16$ & $0,9432 \pm 0,0010$ & & \\
\hline$B A-43 B$ & & & 129,7 & 465,7 & $0,81 \pm 0,02$ & $0,7299 \pm 0,0023$ & & \\
\hline BA-28A & & & 265,1 & 119,6 & $6,53 \pm 0,13$ & $0,8834 \pm 0,0015$ & & \\
\hline BA-37 & Sienito $^{4}$ & & 298,1 & 682,5 & $1,27 \pm 0,03$ & $0,7403 \pm 0,0014$ & & $1850 \pm 60$ \\
\hline BA-38A & & & 462,5 & 243,9 & $5,58 \pm 0,11$ & $0,8657 \pm 0,0013$ & & \\
\hline $\mathrm{BA}-38 \mathrm{~B}$ & & & 442,1 & 242,8 & $3,35 \pm 0,11$ & $0,8536 \pm 0,0008$ & & \\
\hline $\mathrm{BA}-38 \mathrm{C}$ & & & 464,5 & 145,6 & $9,45 \pm 0,18$ & $0,9396 \pm 0,0010$ & & \\
\hline BA-39A & & & 334,2 & 723,9 & $1,43 \pm 0,03$ & $0,7446 \pm 0,0010$ & & \\
\hline $\mathrm{BA}-41$ & & & 334,4 & $1.120,1$ & $0,84 \pm 0,02$ & $0,7318 \pm 0,0011$ & & \\
\hline GSWB-103 1 & Sienito $^{2}$ & & 192,3 & $1.304,5$ & 0,43 & $0,7189 \pm 0,0001$ & & $2077 \pm 46$ \\
\hline GSWB-103 2 & Monzodiorito² & & 78,8 & $2.353,2$ & 0,1 & $0,7090 \pm 0,0001$ & & \\
\hline GSWB-77 & Monzonito² $^{2}$ & & 144,9 & $1.028,6$ & 0,41 & $0,7185 \pm 0,0001$ & & \\
\hline GSWB-80 1 & Granodiorito² $^{2}$ & & 127,7 & $1.620,7$ & 0,23 & $0,7126 \pm 0,0001$ & & \\
\hline GSWB-75 2 & Sienito $^{2}$ & & 170,6 & $1.096,3$ & 0,45 & $0,7197 \pm 0,0001$ & & \\
\hline GS WB-121 1 & Gnaisse $^{2}$ & & 211,9 & 330,8 & 1,86 & $0,7632 \pm 0,0001$ & & \\
\hline JM-BA-611C & Granito $^{3}$ & & 104 & 529,1 & $0,51 \pm 0,004$ & $0,7206 \pm 0,0002$ & & $1953 \pm 50$ \\
\hline JM-BA-611D & & & 103,5 & 727,8 & $0,41 \pm 0,003$ & $0,7178 \pm 0,0000$ & & \\
\hline JM-BA-611E & & & 125,3 & 867,7 & $0,42 \pm 0,003$ & $0,7178 \pm 0,0000$ & & \\
\hline JM-BA-611I & & & 156,7 & 735,7 & $0,617 \pm 0,01$ & $0,7232 \pm 0,0000$ & & \\
\hline JM-BA-611H & & & 144 & 568,2 & $0,735 \pm 0,01$ & $0,7271 \pm 0,0000$ & & \\
\hline JM-BA-611J & & & 141 & 619,6 & $0,659 \pm 0,01$ & $0,7245 \pm 0,0000$ & & \\
\hline 996 & Sienito $^{5}$ & & 127,1 & $1.009,4$ & 0,3642 & $0,716735 \pm 0,037$ & & \\
\hline 1002 & & & 135,8 & 883,2 & 0,4447 & $0,719331 \pm 0,040$ & & \\
\hline 1008 & & & 229,3 & 655,9 & 1,0112 & $0,736326 \pm 0,021$ & & \\
\hline 1128 & & & 146 & 985 & 0,4287 & $0,719936 \pm 0,022$ & & $2071 \pm 246$ \\
\hline 1139 & & & 158,2 & 725,5 & 0,6307 & $0,724695 \pm 0,044$ & & \\
\hline 1141 & Monzonito $^{5}$ & & 235,7 & $1.259,2$ & 0,5414 & $0,723446 \pm 0,047$ & & \\
\hline 1149 & Sienito $^{5}$ & & 137,3 & $1.314,9$ & 0,302 & $0,713715 \pm 0,061$ & & \\
\hline 1216 & & & 191,43 & 794,4 & 0,697 & $0,725691 \pm 0,019$ & & \\
\hline 1218 & & & 134,62 & $1.944,4$ & 0,2003 & $0,71119 \pm 0,023$ & & \\
\hline 1222 & & & 107,4 & $2.056,6$ & 0,1511 & $0,709628 \pm 0,016$ & & \\
\hline 1146 & & & 193,1 & 384,9 & 1,4511 & $0,746839 \pm 0,025$ & & \\
\hline 1157 & Laguna $^{5}$ & & 205,3 & 689,9 & 0,8607 & $0,732338 \pm 0,057$ & & \\
\hline 1158 & & & 183,81 & 947,4 & 0,5612 & $0,7237 \pm 0,028$ & & \\
\hline 1160 & & & 270,8 & $1.236,1$ & 0,6337 & $0,724054 \pm 0,015$ & & \\
\hline 1162 & & & 238,07 & $1.544,7$ & 0,4458 & $0,719403 \pm 0,034$ & & \\
\hline 1202 & Paratinga $^{5}$ & & 145,9 & 88,3 & 4,7793 & $0,864667 \pm 0,028$ & & $1935 \pm 234$ \\
\hline 969 & Cara Suja ${ }^{5}$ & & 309,4 & 911 & 0,9824 & $0,7355 \pm 0,0001$ & & \\
\hline 974 & Sienito $^{5}$ & & 339,9 & $1.149,5$ & 0,8553 & $0,72939 \pm 0,0001$ & & \\
\hline
\end{tabular}


Anexo 1. Continuação.

\begin{tabular}{|c|c|c|c|c|c|c|c|c|}
\hline $\mathrm{N}^{\circ}$ de Campo & Rocha & Material & $\begin{array}{c}\mathrm{Rb} \\
\text { (ppm) }\end{array}$ & $\begin{array}{c}\text { Sr } \\
\text { (ppm) }\end{array}$ & ${ }^{87} \mathrm{Rb} /{ }^{86} \mathrm{Sr}$ & ${ }^{87} \mathrm{Sr} /{ }^{86} \mathrm{Sr}$ & $\% \mathrm{~K}$ & Idade (Ma) \\
\hline 979 & & & 316,8 & 843,9 & 1,0858 & $0,73613 \pm 0,0001$ & & \\
\hline 982 & Cara Suja & & 329,5 & 453,7 & 2,1007 & $0,76861 \pm 0,0001$ & & \\
\hline 983 & & & 260,6 & 559,9 & 1,3463 & $0,74581 \pm 0,0009$ & & \\
\hline 985 & Ceraíma ${ }^{5}$ & & 187,8 & $1.519,2$ & 0,3576 & $0,715466 \pm 0,019$ & & \\
\hline 1170 & Sienito $^{5}$ & & 175,2 & $6.191,6$ & 0,0818 & $0,708121 \pm 0,087$ & & \\
\hline 1173 & Ceraíma ${ }^{5}$ & & 235,65 & 2314 & 0,2946 & $0,714041 \pm 0,027$ & & $2066 \pm 194$ \\
\hline 1188 & Sienito $^{5}$ & & 190,7 & 974,7 & 0,5659 & $0,722790 \pm 0,047$ & & \\
\hline 1200 & Ceraíma ${ }^{5}$ & & 196,5 & $1.762,1$ & 0,3226 & $0,715250 \pm 0,014$ & & \\
\hline 1009 & Estreito $^{5}$ & & 178,68 & $1.347,1$ & 0,3837 & $0,716717 \pm 0,022$ & & \\
\hline 1014 & & & 236,89 & $1.492,8$ & 0,459 & $0,717659 \pm 0,013$ & & \\
\hline 1226 & Monzonito 5 & & 205,9 & 798,29 & 0,7546 & $0,728331 \pm 0,011$ & & \\
\hline 1228 & Estreito 5 & & 157,1 & 477,3 & 0,952 & $0,735404 \pm 0,041$ & & \\
\hline \multirow[t]{4}{*}{1232} & & & 183,1 & 416,9 & 1,2704 & $0,745497 \pm 0,025$ & & \\
\hline & Granito $^{3}$ & Biotita & & & & & 6 & $1683 \pm 21$ \\
\hline & Granito3 & Biotita & & & & & 3,6 & 1361 \\
\hline & Granito & Biotita & & & & & 6,4 & 1748 \\
\hline
\end{tabular}

*Amostras do Complexo Gnáissico Migmatítico Riacho de Santana.

${ }^{1}$ Jardim de Sá et al. (1976); ${ }^{2}$ Fernandes et al. (1982); ${ }^{3}$ Mascarenhas et al. (1989); ${ }^{4}$ Brito Neves et al. (1980); ${ }^{5}$ Rosa (1999). 